\title{
Los itinerarios de ocio desde la investigación: tendencias, retos y aportaciones
}

\author{
Leisure Itineraries from a Research Perspective: \\ Trends, Challenges and Contributions
}

Caminhos de pesquisa de lazer: tendências, desafios e contribuições

\author{
María Jesús Monteagudo \\ Manuel Cuenca \\ Universidad de Deusto
}

\section{Resumen}

Los itinerarios de ocio forman parte de los nuevos temas de investigación asociados a los Estudios de Ocio. Su conocimiento nos aproxima a los procesos relacionados con el nacimiento, desarrollo y ocaso de nuestros hobbies y aficiones. Nos ayudan a comprender nuestro ocio y su incidencia en la satisfacción de vida, pero también permiten esclarecer la función que estas prácticas tienen respecto a nuestra autorrealización, identificación y hábitos de salud asociados a la calidad de vida. El artículo se detiene en la precisión del concepto y analiza las principales corrientes de investigación que nos aproximan al conocimiento de los itinerarios de ocio. Los autores revisados, fundamentalmente norteamericanos, abordan el tema desde una mirada amplia que, por un lado, cuestiona la incidencia de la continuidad y el cambio en la conformación de las historias de ocio y, por otro, analiza la relevancia de las diferencias interpersonales en la evolución de dichos itinerarios.

Desde un enfoque estrictamente académico, una de las principales aportaciones de la aplicación del concepto itinerario al estudio del ocio reside en la consolidación del tratamiento del ocio como proceso. Lo que nos

\section{Abstract}

Leisure itineraries are part of the new research topics associated with Leisure Studies. Its knowledge brings us closer to the processes related to the birth, development and decline of our hobbies and interests. It helps us understand our leisure and its impact on life satisfaction, but also sheds light on the role of practices that have to do with our self-identification and health habits associated with the quality of life. The article focuses on the accuracy of the concept and discusses the main directions of research, enabling an approach to the current knowledge about itineraries. The authors referred to, mainly Americans, questions the impact of continuity and change and, on the other hand, analize the impact of interpersonal differences in the evolution of itineraries.

From a strictly academic approach, one of the main contributions of the application of the concept of leisure itineraries to the study of consolidation lies in the treatment of leisure as a process. This point of view moves us away from the study of purely objective aspects and leads us to personal implications, without which the meaning of leisure experience is difficult 
separa del estudio de los aspectos puramente objetivos para introducirnos en implicaciones personales sin las cuales resulta difícil comprender el significado de la experiencia de ocio. Al final se exponen los retos a los que nos abre el estudio del tema y, más detenidamente, las aportaciones que supone tanto para la orientación de la oferta educativa como para la implementación de una pedagogía del ocio acorde con la actualidad. El estudio de los itinerarios de ocio permite reforzar la relevancia del ocio como factor de desarrollo humano a lo largo de la vida y legitima su impulso a través de políticas específicas, modelos de gestión y medidas concretas de intervención.

PALABRAS CLAVE: ocio, itinerario de ocio, experiencia de ocio, ciclo vital, continuidad, cambio, estilo de vida.

\section{Resumo}

Itinerários de lazer fazem parte dos tópicos de investigação novas associadas Estudos do Lazer. Seu conhecimento nos aproxima os processos relacionados com o nascimento, desenvolvimento e declínio dos nossos hobbies e interesses. Ela nos ajuda a entender o nosso lazer e seu impacto sobre a satisfação com a vida, mas também lança luz sobre o papel das práticas que têm a ver com a nossa auto-identificação e hábitos de saúde associados com a qualidade de vida. $\mathrm{O}$ artigo centra-se na precisão do conceito e discute as principais direções de pesquisa, permitindo uma aproximação com o conhecimento atual sobre itinerários. Os autores referidos, principalmente americanos, perguntas o impacto da continuidade e mudança e, por outro lado, analisar o impacto das diferenças interpessoais na evolução de itinerários.

De uma abordagem estritamente académica, uma das principais contribuições da aplicação do conceito de itinerários de lazer para o estudo da consolidação reside no tra- to understand. At the end of the paper, the challenges the study opens and the contributions involving both the orientation of the educational offer and the pedagogy of leisure are presented. The study of leisure itineraries allows us to reinforce the importance of leisure as a factor of human development throughout life and legitimizes its support through specific policies, management models and intervention actions.

KEY WORDS: leisure, leisure itineraries, leisure experiences, life cycle, continuity, change, life style.

\section{Resumo}

Itinerários de lazer fazem parte dos tópicos de investigação novas associadas Estudos do Lazer. Seu conhecimento nos aproxima os processos relacionados com o nascimento, desenvolvimento e declínio dos nossos hobbies e interesses. Ela nos ajuda a entender o nosso lazer e seu impacto sobre a satisfação com a vida, mas também lança luz sobre o papel das práticas que têm a ver com a nossa auto-identificação e hábitos de saúde associados com a qualidade de vida. $\mathrm{O}$ artigo centra-se na precisão do conceito e discute as principais direções de pesquisa, permitindo uma aproximação com o conhecimento atual sobre itinerários. Os autores referidos, principalmente americanos, perguntas o impacto da continuidade e mudança e, por outro lado, analisar o impacto das diferenças interpessoais na evolução de itinerários.

De uma abordagem estritamente académica, uma das principais contribuições da aplicação do conceito de itinerários de lazer para o estudo da consolidação reside no tratamento de lazer como um processo. Este ponto de vista nos afasta do estudo de aspectos puramente objetivos e nos leva a implicações pessoais, sem o qual o significado da experiência de lazer é difícil de 
tamento de lazer como um processo. Este ponto de vista nos afasta do estudo de aspectos puramente objetivos e nos leva a implicações pessoais, sem o qual o significado da experiência de lazer é difícil de entender. No final do trabalho, os desafios que o estudo abre e as contribuições que envolvem tanto a orientação da oferta educativa e da pedagogia de lazer são apresentados. O estudo dos itinerários de lazer nos permite reforçar a importância do lazer como fator de desenvolvimento humano ao longo da vida e legitima o seu apoio através de políticas específicas, modelos de gestão e ações de intervenção.

PALAVRAS-CHAVE: lazer, roteiros de lazer, as experiências de lazer, ciclo de vida, continuidade, mudança, estilo de vida.

\section{Introducción}

El conocimiento del ocio y sus manifestaciones en la vida de las personas y de las comunidades actuales está abriendo nuevas áreas de investigación llenas de interés y posibilidades. Más allá de la mera ocupación de los tiempos libres, las investigaciones del momento se asoman a temas tan novedosos como el "ocio experiencial" (Cuenca, Aguilar y Ortega, 2010:44-55), las aportaciones del ocio a la calidad de vida (Jackson, 2006) y "la salud personal o familiar” (Bellver, 2005: 54-55) o la importancia del ocio a lo largo de la vida.

Los itinerarios de ocio tratan de esto último, del ocio a lo largo del tiempo de nuestras vidas, del nacimiento, evolución y ocaso de nuestras prácticas de ocio y nuestras aficiones. Nadie cuestiona en las sociedades contemporáneas la profunda revalorización que ha experimentado el fenómeno del ocio, múltiples razones lo avalan. Entre las más explícitas está el papel que desempeña como motor de crecimiento económico y social, al amparo de las denominadas industrias del ocio. Existe también plena conciencia de que el ocio es un derecho humano que puede con- entender. No final do trabalho, os desafios que o estudo abre e as contribuições que envolvem tanto a orientação da oferta educativa e da pedagogia de lazer são apresentados. O estudo dos itinerários de lazer nos permite reforçar a importância do lazer como fator de desenvolvimento humano ao longo da vida e legitima o seu apoio através de políticas específicas, modelos de gestão e ações de intervenção.

PALAVRAS-CHAVE: lazer, roteiros de lazer, as experiências de lazer, ciclo de vida, continuidade, mudança, estilo de vida.

\section{Introduction}

The knowledge of leisure and its manifestations in the lives of individuals and communities today is opening up new areas of research that are full of interest and possibilities. Beyond the mere occupation of free time, current research studies deal with new issues such as experimental leisure (Cuenca, Aguilar \& Ortega, 2010:44-55), the contributions of leisure to the quality of life (Jackson, 2006) and personal or family health (Bellver, 2005: 54-55) or the importance of leisure throughout life.

Leisure itineraries focus on the latter, on leisure throughout our lifetime, from the birth, evolution and decline of our leisure practices and hobbies. No one questions in contemporary societies the deep appreciation that the leisure phenomenon has experienced, as many reasons support it. Some of these explicitly include the role it plays as the driving force of economic and social growth, under the so-called leisure industries. There is also full awareness that leisure is a human right that can help us to achieve a better life. 
tribuir a la realización de una vida mejor.

Los itinerarios de ocio constituyen el marco epistemológico idóneo para abordar la naturaleza psicosocial del ocio y su carácter procesual, como fenómeno que acompaña a la persona a lo largo de su existencia. Desde el enfoque del ciclo vital y, apoyados en las corrientes teóricas que han profundizado en el estudio del ocio a lo largo de la vida se plantean aquí cuestiones acerca de la evolución del ocio, los patrones de cambio que subyacen a este proceso, la posibilidad de comprender a las personas en función de tales cambios, la capacidad predictiva de estos conocimientos y su valor a la hora de favorecer la persistencia del ocio a lo largo de la vida e impulsar su papel como factor de desarrollo personal. En definitiva, la incorporación del concepto itinerario al estudio del ocio en el marco del ciclo vital aporta nueva luz para encontrar respuesta a estos interrogantes.

\section{El itinerario de ocio: una aproximación al concepto}

El ocio, en cuanto experiencia subjetiva, condicionada por factores internos y externos, diferentes en cada individuo, da lugar a la existencia de distintos patrones de ocio que se investigan bajo el concepto de Estilos de Vida en Ocio (EVO) (Stebbins, 2000). En general, la noción de Estilo de Vida hace referencia al patrón individual de cogniciones, emociones y acciones que contribuyen a la identidad personal y social de un individuo (Uth, 1996). Aplicado al ocio, este concepto se concibe como el "patrón o forma de vivir el mundo de cada individuo, como expresión de sus actividades, intereses y opiniones con relación al ocio" (Bigné, Font y Andreu, 2000:2 14). Si a esta variabilidad entre individuos, que legitima la existencia de diferentes estilos de ocio, se le añade el carácter dinámico del ocio (enfoque longitudinal), emerge, como tarea ineludible, la identificación de los patrones
Leisure itineraries are an ideal epistemological framework to address the psychosocial nature of leisure and its procedural nature, as a phenomenon that accompanies the person throughout his/her lifetime. Based on a life-cycle approach, and supported by the theoretical currents that have delved into the study of lifelong leisure, a number of issues are raised here about the evolution of leisure, the patterns of change underlying this process, the possibility of understanding people on the basis of such changes, the predictive power of this knowledge, and its value in encouraging the persistence of leisure throughout life and promoting its role as a factor of personal development. Ultimately, the incorporation of the concept of itinerary into the study of leisure as part of the life cycle brings new light to find answers to these questions.

1. The leisure itinerary: an approach to the concept

Leisure, as a subjective experience, influenced both by internal and external factors, different in each individual, results in the existence of different leisure patterns that are studied under the concept of Leisure Lifestyles (Stebbins, 2000). In general, the concept of Lifestyle refers to the individual pattern of cognitions, emotions and actions that contribute to an individual's personal and social identity (Uth, 1996). When it is applied to leisure, this concept is seen as the pattern or way of experiencing the world each individual has, as an expression of his/her activities, interests and opinions in relation to leisure (Bigné, Font \& Andreu, 2000: 214). If, in addition to this variability between individuals, which legitimises the existence of different styles of leisure, we consider the dynamic nature of leisure (longitudinal approach), there emerges the identification of leisure patterns that peo-

[ 106 ] - María Jesús Monteagudo y Manuel Cuenca

SIPS - PEDAGOGÍA SOCIAL. REVISTA INTERUNIVERSITARIA [1139-1723 (2012) 20, 103-135] • TERCERA ÉPOCA 
de ocio que las personas desarrollan a lo largo de la vida.

En este marco, el concepto de itinerario puede contribuir a profundizar y sistematizar el conocimiento existente sobre las transformaciones que el ocio experimenta en los distintos periodos de la vida y los factores que propician tales cambios. La idoneidad de este concepto descansa, por un lado, en su capacidad para preservar la naturaleza procesual del ocio y el protagonismo de la persona, único responsable de la integración del conjunto de sus experiencias de ocio en un todo con sentido, que es su historia vital. Por otro, su relevancia radica en la posibilidad que proporciona de ahondar en el devenir dinámico del ocio, delimitando fases concretas, esclareciendo tendencias y patrones de cambio que convierten la historia de ocio ya vivida en una base sólida para delinear el futuro de dichas trayectorias.

El concepto itinerario invita a pensar en el ocio como un camino que se va completando al andar, cada vez que optamos libremente, actuamos, sentimos y volvemos a pensar en cuál será nuestra próxima experiencia de ocio. Cada una de las fases por las que este camino transcurre adquiere un sentido, un significado y un valor distinto para el individuo, cumple unas funciones y deja una huella diferente en quien lo cubre. Estas fases se representan, habitualmente, en tres momentos bien diferenciados:

- inicio (I): tiene lugar en el momento en que la persona comienza su relación con el ocio,

- desarrollo: tras el inicio, la interacción de la persona con el ocio puede tomar distintas direcciones, optando por la continuidad (C) de algunas prácticas, por el abandono temporal de las mismas, si las prácticas abandonadas se acaban retomando (reinicio - R) o por la sustitución (S) de una actividad por otra,

- y finalmente, la resolución del itinerario, con la que la persona pone fin a su parti- ple develop throughout their lifetime as an unavoidable task.

Within this framework, the concept of itinerary may contribute to gain a deeper knowledge and to systematise the existing knowledge about the transformations that leisure experiences in the different life periods and the factors conducive to such changes. The suitability of this concept rests, on the one hand, on its ability to preserve the procedural nature of leisure and the leading role of the individual, solely responsible for the integration of all his/her leisure experiences into a meaningful whole, which is his/her whole life history. On the other hand, its relevance lies in the possibility it provides to delve into the dynamic evolution of leisure, outlining specific steps, clarifying trends and patterns of change that make the history of leisure already experienced into a solid foundation for shaping the future of these paths.

The itinerary concept invites us to understand leisure as a path to be made as we go, every time we choose freely, act, feel and rethink about what our next leisure experience will be. Each of the stages through which this path goes through has a different sense, meaning and value for the individual, plays a number of functions and leaves a different imprint on those completing it. These stages are usually represented by three distinct moments:

- Start: it takes place at the moment when the individual starts his/her relationship with leisure,

- Development: after the start stage, an individual's interplay with leisure can take different directions, and may opt for the continuity of some practices, for their temporary abandonment, if the abandoned practices are eventually resumed (restart), or for the substitution of one activity for another,

- and finally, the resolution of the itinerary, with which the individual ends 
cipación en ocio a través del "abandono definitivo" (A).

Según lo expuesto, el itinerario de ocio hace referencia a la trayectoria de ocio que el individuo ha desarrollado a lo largo de su vida; acoge, por tanto, el conjunto de experiencias de ocio que la persona ha disfrutado en su historia personal. Un itinerario se "inicia en el instante en que el sujeto toma contacto con el ocio; se desarrolla durante un periodo de tiempo más o menos amplio en el que se dedica a la práctica de una o varias actividades de ocio y finaliza cuando se abandona toda relación con este ámbito como participante" $^{1}$.

Es importante matizar que el concepto de itinerario ha sido empleado, principalmente, en el ámbito deportivo (Puig y Masnou, 1988; Masnou y Puig, 1995), razón por la cual la adaptación al fenómeno del ocio requiere ciertos matices con relación a las fases que conforman un itinerario de ocio.

Si se asume, tal y como se plantea la teoría del ocio humanista (Cuenca, 2000), que el ocio forma parte inherente de la naturaleza humana, es decir, que constituye una necesidad que la persona experimenta por el hecho de ser tal, entonces, hay que admitir que el ocio nos acompaña durante toda la existencia. De tal forma que, la resolución o el momento de ruptura definitiva, vendrá impuesta por el final de la vida o, en todo caso, por las circunstancias en las que la persona deja de tener el control de sus facultades. Por tanto, a diferencia de lo que sucede en el ámbito deportivo, el estudio de la evolución de los itinerarios de ocio se centra, fundamentalmente, en dos de las tres fases planteadas; concretamente, inicio y desarrollo; aunque obviamente, sí puede hablarse de resolución, considerando el final de ciertas prácticas concretas.

La revisión de la literatura sobre itinerarios apunta al proceso evolutivo y las circunstancias personales y sociales que acom- his/her participation in leisure through the permanent abandonment.

As explained above, the leisure itinerary refers to the history of leisure that the individual has developed throughout his/her lifetime; it therefore comprises the set of leisure experiences that the individual has enjoyed throughout his/her personal history. An itinerary "starts at the very moment an individual becomes in contact with leisure; it is developed over a longer or shorter period of time that he/she is engaged in the practice of one or more leisure activities, and ends when you leave any relation with this area as a participant" 1 .

It should be highlighted that the concept of itinerary has been mainly used in the sports sphere (Masnou \& Puig, 1995; Puig \& Masnou, 1988), which is why the adaptation to the leisure phenomenon has some subtle differences in meaning in relation to the stages that make up a leisure itinerary.

If it is assumed, as the theory of humanist leisure suggests (Cuenca, 2000), that leisure is an inherent part of human nature, that is, which is a necessity that the individual experiences by virtue of being such, then, it must be admitted that leisure accompanies us throughout our lifetime. In this way, the resolution or time of final abandonment will be enforced by the end of life or, in any case, by the circumstances in which the individual ceases to have control of his/her faculties. Thus, unlike what happens in sport, the study of the evolution of leisure itineraries focuses primarily on two of the three phases involved; specifically, start and development; although we can obviously talk about resolution, considering the end of certain specific practices.

The review of the literature on itineraries points to the evolutionary process and the personal and social circumstances that 
pañan a cada etapa vital, como aspectos que delinean con mayor contundencia las transformaciones que el ocio experimenta a lo largo de la vida. Las teorías de la Psicología del Desarrollo (Havighurst, 1973; Levinson, 1978; Erikson, 1985) han aportado un marco teórico propicio para intentar dar respuesta a los interrogantes anteriores.

El apartado que sigue tiene como objetivo revisar las principales aproximaciones teóricas interesadas en esclarecer la interacción que se establece entre ocio y cambio desde el enfoque del ciclo vital. En ellas se pretende identificar en qué medida los patrones de cambio que el proceso evolutivo imprime en la conducta humana afectan también a los comportamientos de ocio y su evolución en los distintos periodos de la existencia. Estas aproximaciones sugieren, además, la existencia de variables, a partir de las cuales es posible predecir el tipo de cambio que experimentarán los patrones de ocio en unas personas y no en otras.

A pesar de que buena parte de los postulados defendidos por estas teorías toman como punto de referencia la visión cronológica del ciclo vital y las transformaciones internas que ello conlleva, relativizan el papel determinante de la variable edad y refuerzan el influjo de la dimensión social de la persona como variable explicativa a tener en cuenta en la interpretación de los cambios que experimentan los itinerarios de ocio a lo largo de la vida (Martínez, 2002; Janke, Davey y Kleiber, 2006).

\section{Principales corrientes y variables funda- mentales en el estudio de los itinerarios de ocio}

Frente a las corrientes teóricas que focalizaban el estudio de las funciones del ocio y de su contribución al desarrollo evolutivo en las etapas de la infancia y la juventud, hoy resulta incuestionable que el itinerario de ocio debería iniciarse durante la infancia y extenderse hasta las últimas etapas de la vida, dado accompany each life stage, and regards them as aspects more forcefully outlining the changes that leisure experiences throughout life. The theories of Developmental Psychology (Erikson, 1985; Havighurst, 1973; Levinson, 1978) have provided a suitable theoretical framework to try to answer the above questions.

The following section aims to review the main theoretical approaches concerned with clarifying the interaction established between leisure and change from a life-cycle approach. They will identify the extent to which the patterns of change that the evolutionary process leaves on human behaviour also affect leisure behaviour patterns and their evolution in the different periods of existence. In addition, these approaches also suggest the existence of variables, based on which it is possible to predict the type of change that leisure patters will experience in some people and not in others.

Although many of the principles defended by these theories take the timeline view of the life cycle and the internal changes it entails as a reference point, they relativise the determining role of the age variable and reinforce the influence of the individual's social dimension as an explanatory variable to consider in the interpretation of the changes that leisure itineraries experience throughout life.

\section{Main trends and key variables in the study of Leisure Itineraries}

Faced with the latest theoretical trends, focused on the functions of leisure and their contribution to the evolutionary stages of childhood and youth, today it is unquestionable that the leisure itinerary should start in childhood and extend into the later stages of life, since leisure is a constant fea- 
que el ocio es una constante en el devenir humano. Esta ampliación del enfoque, con el que ha de abordarse el ocio, tiene su origen en las primeras teorías que definieron el proceso evolutivo como un periodo de crecimiento y de cambio que incluye también la fase de la edad adulta y etapas posteriores. La idea de declive, vinculada hasta entonces a estas etapas tardías de la vida, comenzó a perder fuerza a favor de posturas que conciben la edad adulta y el fenómeno del desarrollo en general, como un proceso susceptible de un crecimiento sostenido de aprendizaje $y$, por tanto, de cambios que subrayan la plasticidad o generatividad de la condición humana en cualquier etapa de la vida (Erikson, 1985).

Así mismo, el abordaje del ocio desde los presupuestos del Ciclo Vital, planteó en sus inicios "la naturaleza derivada de las experiencias de ocio con respecto a otros cambios en el desarrollo evolutivo" (Kleiber, 1999:33). Según este planteamiento, el itinerario de ocio es resultado y reflejo de los cambios habidos en las diferentes etapas y facetas de la vida de una persona. Ciertamente, la capacidad de ajuste y adaptación del ocio a las circunstancias vitales de cada individuo es uno de los atributos que contribuyen a su puesta en valor. Sin embargo, la relación que se establece entre el ocio y otros ámbitos de la vida, no es unívoca, sino bidireccional. De manera que si el ocio depende, en buena medida, de los cambios habidos en el individuo como consecuencia de su proceso de maduración y otras circunstancias vitales, también es cierto que el ocio puede propiciar modificaciones importantes en los estilos de vida de las personas, mediante la traslación de valores y actitudes relevantes en el ocio hacia otros contextos vitales.

"El ocio y el tiempo libre [...] se convierten en fundamento de valores y de nuevas valoraciones que penetran y transforman otras esferas de la vida cotidiana. El ocio, en definitiva, es un factor de cambio y de ture in human evolution. This extension of the approach, under which leisure has to be addressed, has its origin in the early theories that defined the evolutionary process as a period of growth and change that also includes the stage of adulthood and later life. The idea of decline, previously linked to these later stages of life, began to wane in favour of positions that conceive adulthood and the phenomenon of overall development as a process capable of sustained growth in learning, and therefore, in changes that underscore the plasticity or generativity of the human condition at any stage of life (Erikson, 1985).

Also, the approach to leisure according to the life-span perspective first raised "the derivative nature of leisure experiences over other changes in the evolutionary development" (Kleiber, 1999:33). Under this approach, the leisure itinerary results from and reflects the changes in the various stages and aspects of a person's life. Certainly, the ability that leisure has to adjust and adapt to each individual's life circumstances is one of the attributes that contribute to its enhancement. However, the relationship established between leisure and other areas of life is not univocal but bidirectional. Therefore, if leisure depends to a large extent on the changes in the individual as a result of his/her maturation process and other life circumstances, it is also true that leisure can lead to significant changes in the lifestyles of people by the shifting of values and attitudes relevant to leisure to other life contexts.

"Leisure and free time...become the
foundation of values and new assess-
ments that penetrate and transform
other areas of everyday life. Leisure,
in short, is a factor of social change and
development which can cause changes
in areas such as family life, work, po-

[ 110 ] - María Jesús Monteagudo y Manuel Cuenca

SIPS - PEDAGOGÍA SOCIAL. REVISTA INTERUNIVERSITARIA [1139-1723 (2012) 20, 103-135] • TERCERA ÉPOCA 
evolución social que puede provocar cambios en sectores como la vida familiar, el trabajo, la participación política y cultural, o la vida religiosa." (Trilla, 1984:43)

De hecho, sería tan deseable como esperable que a medida que el ocio se vaya consolidando en las generaciones más jóvenes como un valor central, principal fuente, no solo de diversión, sino también de sentido vital, su impacto en otras esferas de la vida -hasta el momento menos explícito-, se observara como un fenómeno cada vez más común ${ }^{2}$.

Los anteriores matices, concebidos como avances ineludibles en la investigación sobre ocio y ciclo vital, no ponen en peligro, sin embargo, la vigencia de presupuestos teóricos previamente defendidos desde la Psicología del Desarrollo. Partiendo de enfoques diversos y asumiendo variaciones clasificatorias entre diferentes autores (Havighurst, 1973; Erikson, 1985; Gordon, Gaitz y Scott, 1976; Levinson, 1978), casi todos estructuran el proceso vital en cuatro fases, destacando, en cada una de ellas, un aspecto o tarea central (Havighurst, 1973) que impone la dirección del desarrollo evolutivo y orienta, con evidentes variaciones en cada persona, la búsqueda y consolidación de unas conductas de ocio y no otras. Tales conductas se hallan al servicio de las necesidades u objetivos en los que se centran los esfuerzos del individuo en cada etapa, modulando también las necesidades, preferencias, beneficios y barreras que conlleve la participación en ocio en cada periodo. Añadiendo a estas Teorías del Desarrollo el enfoque psicosocial necesario, afirmamos que será el influjo del propio proceso evolutivo así como las circunstancias personales y sociales de cada individuo, las que van a caracterizar el patrón de ocio que conforma su itinerario.

La siguiente cuestión a resolver remite directamente a los cambios que el ocio experimenta durante el ciclo vital, en general, y en cada etapa, en particular. El estudio de los itinerarios de ocio desde un enfoque macro, que litical and cultural involvement or religious life" (Trilla, 1984: 43)

In fact, it would be as desirable as expected that, as leisure becomes consolidated in the younger generations as a core value, the main source not only of enjoyment but also of vital sense, its impact on other areas of life -far less explicit up to now-, were regarded as an increasingly common phenomenon ${ }^{2}$.

The above nuances, conceived as inevitable advances in research on leisure and life cycle, do not compromise, however, the validity of theoretical assumptions previously defended by Developmental Psychology. If we take into consideration various approaches and start by assuming that there are qualifying variations between different authors (Erikson, 1985; Havighurst, 1973; Gordon, Gaitz \& Scott, 1976; Levinson, 1978), almost all of them divide the vital process into four stages, and emphasise in each a core aspect or task (Havighurst, 1973). This sets the direction of evolutionary development and guides, with obvious variations in each person, the search for and consolidation of some leisure behaviour patterns and not others. Such behaviours are serving the needs or objectives that focus the efforts of the individual at every stage, at the same time as they modulate the needs, preferences, benefits and barriers that lead to the participation in leisure in each period. If we incorporate an appropriate psychosocial approach to these Development Theories, we can state that it will be the influence of the evolutionary process itself and the personal and social circumstances of each individual that will characterise the leisure pattern that will make up his/her itinerary.

The next issue to consider relates directly to the changes that leisure experiences through the life span, in general, and at each stage, in particular. The study of 
busca la existencia de un patrón o tendencia dominante en tales cambios, ha despertado un enorme interés en la comunidad científica de ocio y ha sido, al mismo tiempo, objeto de importantes controversias. La existencia de corrientes teóricas contrapuestas, según las cuales el desarrollo evolutivo imprime una u otra dirección a las conductas de ocio, ha generado una interesante dialéctica, que aún no está cerrada.

\subsection{La tendencia al cambio}

Una buena parte de las teorías (Gordon, Gaitz y Scott, 1976), defienden la existencia de una correlación negativa entre ocio y ciclo vital, de forma que a medida que aumenta la edad desciende la participación en actividades de ocio. Los resultados obtenidos en diferentes investigaciones sugieren que con la edad varía tanto el contenido de las prácticas de ocio, a favor de actividades de baja intensidad y con escasa presencia de actividad física, como los niveles de participación (considerada en términos de frecuencia), incluso en actividades consideradas sedentarias. Frente a estos planteamientos, que se acogen a los presupuestos defendidos por la Teoría de la Desvinculación (Cumming y Henry, 1961), surgieron, como contrapunto, otras posturas cuyos postulados apuntaban la idea de que un proceso evolutivo exitoso depende del mantenimiento de un estilo de vida activo, al margen de la edad. Esta Teoría de la Actividad (Neugarten, Havighurst y Tobin, 1961), ha tenido importantes repercusiones respecto al ocio, pues este se concibe como un contexto idóneo para que la persona se mantenga activa a medida que envejece.

Si la Teoría de la Desvinculación presentaba el progresivo aislamiento que conlleva el envejecimiento como un proceso no solo inevitable sino deseable para el bienestar psicológico de la persona, los defensores de la leisure itineraries from a macro approach, which seeks the existence of a prevailing pattern or trend in these changes, has aroused great interest among the leisure research community and has been, at the same time, the subject of significant controversy. The existing of conflicting schools of thoughts, according to which the evolutionary development can make leisure behaviour patterns go in either direction, has created an interesting dialectical interplay, which is not closed yet.

\subsection{The tendency to change}

A large number of theories (Gordon, Gaitz \& Scott, 1976) support the existence of a negative correlation between leisure and life-cycle insofar as participation in leisure activities decreases with age. The results obtained from different studies suggest that both the content of leisure practices, in favour of low-intensity activities and scarce physical activity, and the levels of participation (considered in terms of frequency), even in activities regarded as sedentary, vary with age. Bearing these approaches in mind, which benefit from the assumptions defended by the Disengagement Theory (Cumming \& Henry, 1961), other approaches emerged as a counterpoint. These suggested the idea that a successful evolutionary process depended on maintaining an active lifestyle, regardless of age. This Activity Theory (Neugarten, Havighurst \& Tobin, 1961) has had a great impact on leisure, as this is seen as a suitable context for individuals to remain active as they age.

If the Disengagement Theory showed the progressive isolation that comes with aging as a process that is not only inevitable but also desirable for an individual's psychological well-being, those defending the Activity Theory stress that individuals' satisfaction and well-being is 
Teoría de la Actividad, subrayan que la satisfacción y el bienestar de las personas está directamente relacionado con el número de actividades en el que se halle implicado el sujeto. Desde este enfoque, la clave de un proceso de maduración exitoso reside en mantenerse activo. Son numerosas las investigaciones que buscan corroborar la correlación entre el mantenimiento de un rol activo a lo largo de la vida y los beneficios que este estado propicia, principalmente, psicológicos (McClelland, 1982; Sagy, Antonovsky y Adler, 1990; Reitzes, Mutran y Verrill, 1995); sin embargo, los resultados de tales estudios no son del todo consistentes pues se halla sobradamente demostrado que el mero activismo no es garantía de bienestar.

Para la mayor parte de los autores, la verdadera dialéctica se establece entre la tendencia al cambio o a la estabilidad a las que, de manera bipolar, las personas estamos orientadas. Considerando esta tendencia dual, Iso-Ahola (1980.a) afirma en su Teoría del Desarrollo de Ocio, que todo individuo persigue, a través de sus conductas de ocio, un nivel óptimo de activación que varía en las diferentes etapas del ciclo vital. El modelo que Iso-Ahola propone para explicar los cambios en los itinerarios de ocio a lo largo de la vida (Iso-Ahola, 1980.a), establece que la participación en ocio adopta, en potencia, un modelo curvilíneo, atendiendo a las variaciones habidas en cuanto al deseo de novedad o familiaridad que las personas buscan satisfacer con su ocio. La novedad se convierte en el aliciente principal y alcanza su punto máximo durante la edad adulta (temprana y media) y comienza a disminuir, a favor de la búsqueda de familiaridad, a partir de esa etapa. Las necesidades de logro y de cambio que pueden persistir entre personas adultas y mayores se solventan mediante un menor espectro de actividades, más que ampliando el repertorio de ocio o reemplazando prácticas ya conocidas por otras nuevas. Este dato que, a priori, corrobora la correlación negativa entre edad y prácticas de ocio realizadas, tam- directly related to the number of activities in which they are involved. From this perspective, the key to a successful maturation process lies in staying active. $\mathrm{Nu}$ merous studies have sought to corroborate the correlation between maintaining an active role throughout life and the mainly psychological benefits that this state favours (McClelland, 1982; Reitzes, Mutran \& Verrill, 1995; Sagy, Antonovsky \& Adler, 1990); however, the results of such studies are not entirely consistent because it is well- established that mere activism in no guarantee of well-being.

For most authors, the true dialectic is established between the tendency to change or to the stability to which, in a bipolar way, people are prone. Considering this dual trend, Iso-Ahola (1980a), in his Theory of Leisure Development, argues that everyone seeks, through their leisure behaviour, the optimal level of activation that varies in the different life cycle stages. The Model that Iso-Ahola proposes to explain the changes in the leisure itineraries throughout life (Iso-Ahola, 1980a) states that participation in leisure potentially adopts a curvilinear pattern, taking into account the changes occurred regarding the desire for novelty or familiarity that people seek to satisfy with their leisure. The novelty becomes the main attraction and peaks in adulthood (early and middle) and begins to decline in favour of familiarity, from that stage. The needs for achievement and change that can persist among adults and elderly people are solved by a narrower spectrum of activities, rather than expanding the diverse range of leisure practices, or replacing already known practices with new ones. This data that, a priori, supports the negative correlation between age and leisure practices carried out, could also be explained, however, bearing in mind the elderly people's selective perception of their own interests (Kleiber, Walker \& Mannell, 2011). 


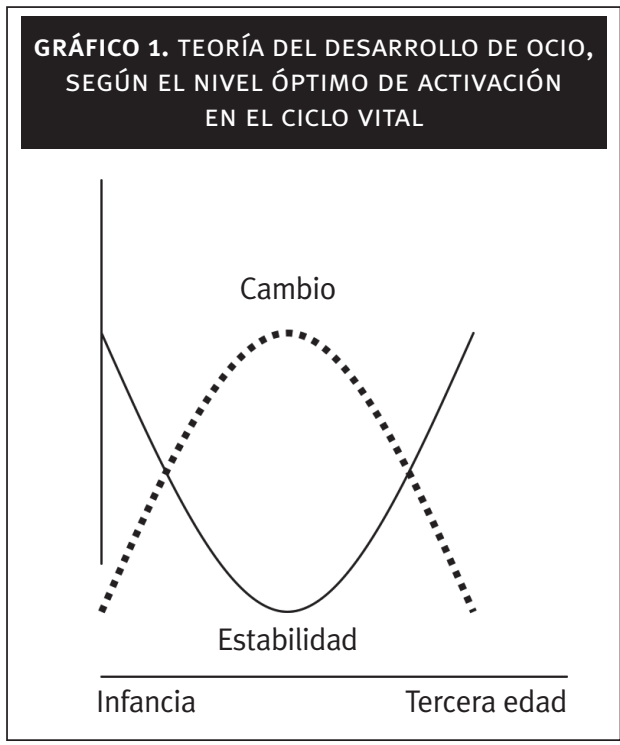

Fuente: Iso-Ahola, 1980a; Kleiber, 1999.

bién podría explicarse sin embargo, atendiendo a un talante más selectivo y conocedor de los propios intereses por parte de las personas mayores (Kleiber, Walker y Mannell, 2011).

Esta línea de pensamiento entiende el ocio como un proceso dialéctico, en el que la persona busca tanto estabilidad como cambio, tanto estructura como variedad y familiaridad como novedad (Iso-Ahola, 1980.b). El reto que subyace a esta dialéctica es descubrir los factores en base a los cuales las personas se decantan por aquella acción de ocio en la que prevalece la continuidad o el cambio, con el objetivo de alcanzar el equilibrio que, en este aspecto, toda persona necesita.

Los resultados de las investigaciones realizadas en este sentido apoyan la continuidad como la tendencia que prevalece en la configuración del itinerario de ocio a lo largo de la vida. La Teoría de la Continuidad de Atchley (1989) refrenda esta línea de pensamiento y defiende desde un enfoque constructivista, que, las personas desempeñan un rol activo en la definición de sí mismos y de su entorno, de sus preferencias, estilos de vida y de ocio. La singularidad que esto conlleva en el proceso

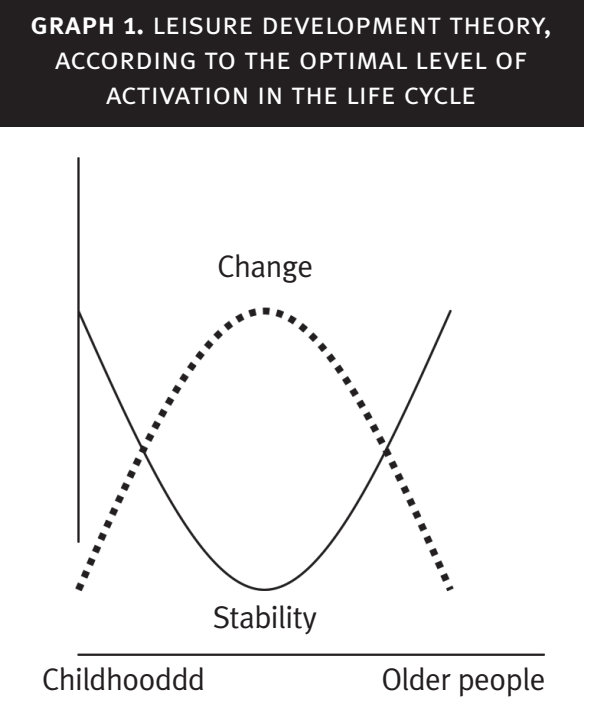

Source: Iso-Ahola, 1980a; Kleiber, 1999.

This line of thought understands leisure as a dialectical process where the individual seeks both stability and change, and structure, variety and familiarity as a novelty (Iso-Ahola, 1980b). The challenge behind this dialectic is to discover the factors based on which individuals opt for that leisure activity where continuity or change prevails, in order to achieve the balance any person needs in this respect.

The results of the research conducted in this regard support continuity as the prevailing trend in shaping the leisure itinerary throughout life. Atchley's Continuity Theory (1989) endorses this line of thought and uses a constructivist approach to defend that individuals play an active role in defining themselves and their environment, their preferences, lifestyles and leisure. This peculiar feature in the maturation process makes it difficult to specify an optimal pattern of overall development, as each person defines this pattern in response to his/her life experiences. According to Atchley, it is not possible to state that individuals' social disengagement or the in-

[ 114 ] - María Jesús Monteagudo y Manuel Cuenca

SIPS - PEDAGOGÍA SOCIAL. REVISTA INTERUNIVERSITARIA [1139-1723 (2012) 20, 103-135] • TERCERA ÉPOCA 
de maduración hace complicado delimitar un patrón óptimo de desarrollo general, pues cada persona define este patrón atendiendo a sus experiencias vitales. Para Atchley, no es posible afirmar que la desvinculación social del individuo o que el incremento de la participación en ocio promueva un aumento de la satisfacción. De acuerdo con estos postulados, el nivel de actividad con el que la persona se encuentra más satisfecha, a medida que envejece, vendrá definido por su historia vital y el patrón de participación en ocio que haya desarrollado habitualmente en etapas anteriores. En definitiva, esta teoría convierte el itinerario de ocio ya vivido en la principal variable a tener en cuenta a la hora de delinear la futura trayectoria de ocio de una persona.

Encontramos numerosas investigaciones que tras analizar la evolución de las prácticas de ocio de población adulta y mayor (Jackson y Dunn, 1988; Searle, Mactavish y Brayley, 1993; Iso-Ahola, Jackson y Dunn, 1994; Armstrong y Morgan, 1998; Iwasaki y Smale, 1998; Lee y King, 2003), hallan en sus resultados, datos suficientes para apoyar esta tendencia a la continuidad en los patrones de ocio. Tales estudios se apoyan en el Modelo de Toma de Decisiones de Ocio (Jackson y Dunn, 1988), según el cual, las conductas de ocio son el resultado de un complejo proceso de toma de decisiones que conduce a las personas a iniciar, cesar, sustituir o continuar una práctica de ocio (Searle, Mactavish y

GRÁFICO 2. PORCENTAJE DE PERSONAS QUE COMIENZAN UNA NUEVA ACTIVIDAD DE OCIO

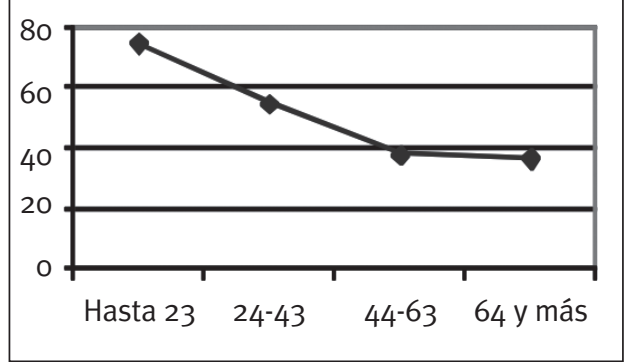

Fuente: Iso-Ahola, Jackson y Dunn, 1994. creased participation in leisure promote an increase in satisfaction. Based on these assumptions, the level of activity with which individuals are more satisfied as they grow older will be defined by their life history and the pattern of participation in leisure that has been usually developed in previous stages. In short, this theory makes the leisure itinerary already experienced become the main variable to be considered when outlining the future course of an individual's leisure.

We found numerous research studies that, after analysing the evolution of leisure practices among adult and older population (Armstrong \& Morgan, 1998; Iso-Ahola, Jackson \& Dunn, 1994; Iwasaki \& Smale, 1998; Jackson \& Dunn, 1988; Lee \& King, 2003; Searle, Mactavish \& Brayley, 1993) revealed insufficient data to support this trend of continuity in leisure patterns. These studies rely on the Model of Leisure Decision-Making (Jackson \& Dunn, 1988), according to which, leisure behaviour patterns are the result of a complex decisionmaking process that leads individuals to start, stop, replace or continue a leisure practice (Searle, Mactavish \& Brayley, 1993). The results show that the number of activities in which an individual is involved decreases with age. Similarly, the number of activities replaced by new ones decreases throughout the maturation process;

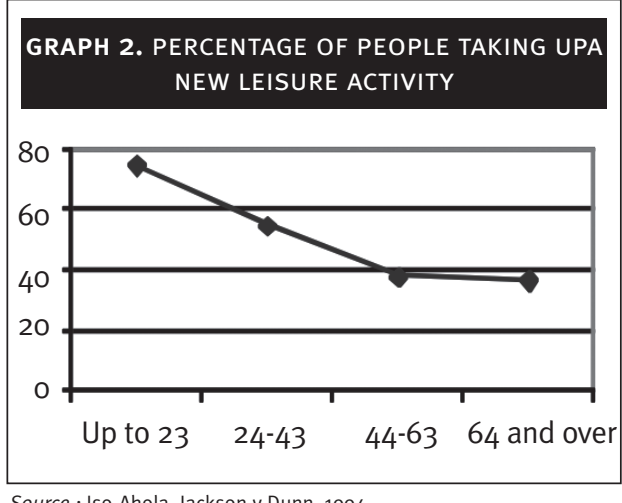

Source : Iso-Ahola, Jackson y Dunn, 1994

LOS ITINERARIOS DE OCIO DESDE LA INVESTIGACIÓN: TENDENCIAS, RETOS Y APORTACIONES [ 115 ] SIPS - PEDAGOGÍA SOCIAL. REVISTA INTERUNIVERSITARIA [1139-1723 (2012) 20, 103-135] • TERCERA ÉPOCA 

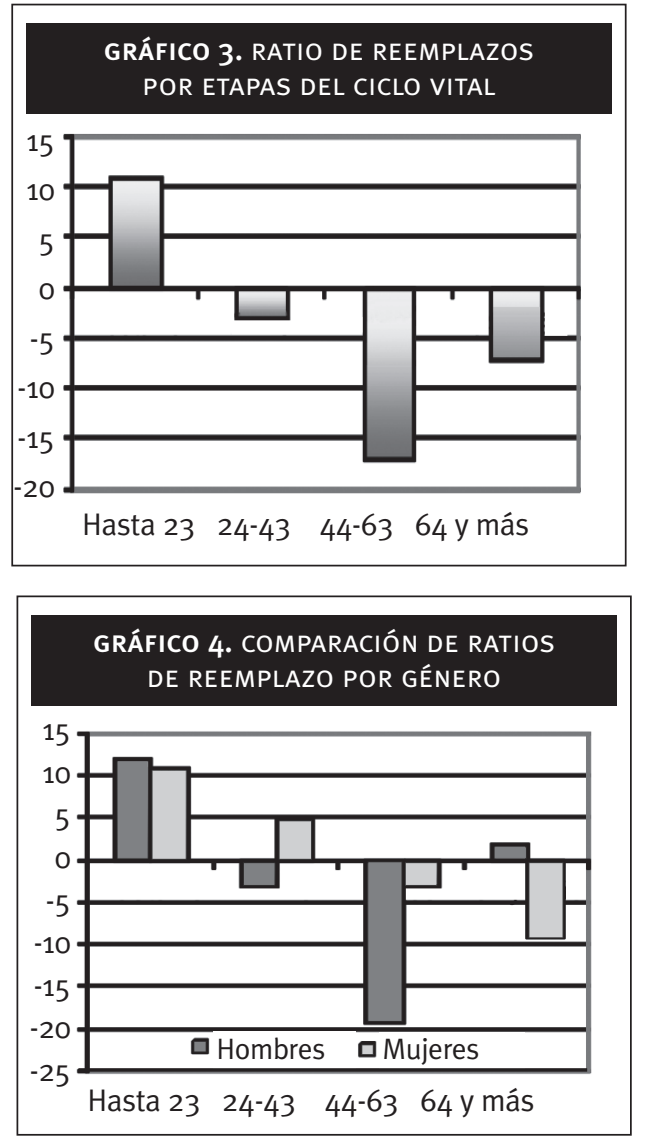

Fuente: Iso-Ahola, Jackson y Dunn, 1994.

Brayley, 1993). Los resultados apuntan que el número de actividades nuevas en las que una persona se implica, disminuye con la edad. De modo similar, el número de actividades sustituidas por otras nuevas desciende a lo largo del proceso de maduración:

El género imprime ciertas diferencias en lo que se refiere al fenómeno del reemplazo. Este se concentra por igual entre hombres y mujeres hasta los 24 años. Después, las sustituciones son inusuales excepto en el caso de las mujeres adultas hasta los 43 años y los hombres mayores de 64 años. En este último caso, dicho repunte sugiere la persistencia de un deseo de novedad aún latente.

Estos resultados, obtenidos de una de las investigaciones de referencia en esta área de

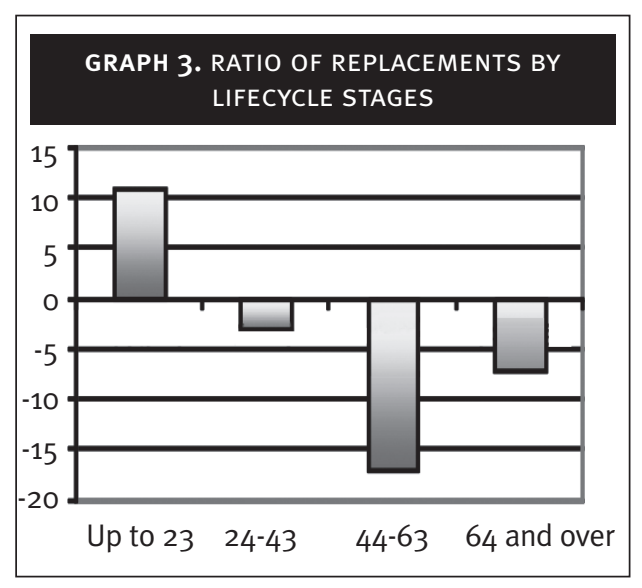

GRAPH 4. COMPARISON OF REPLACEMENT RATIOS BY GENDER

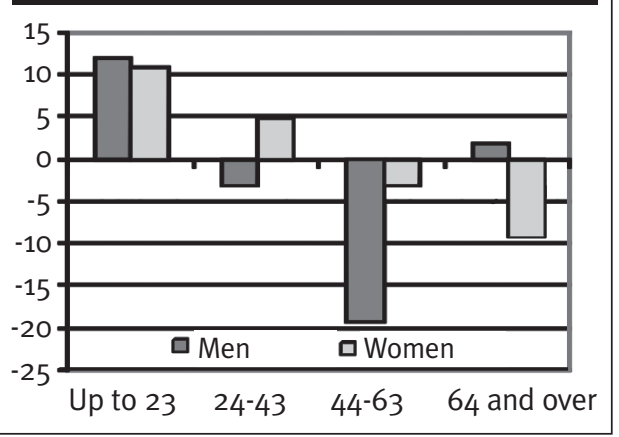

Source: Iso-Ahola, Jackson y Dunn, 1994.

There are gender differences related to the phenomenon of replacement. They are equally balanced between men and women up to the age of 24 years. Then, replacements are unusual except in the case of adult women aged up to 43 years and men older than 64 years. In the latter case, the upturn suggests the persistence of a still latent desire for novelty.

These results, obtained from a benchmark research study in this field, defend the continuity of leisure interests throughout life and reveal, according to Iso-Ahola's Leisure Development Theory, that this trend consolidates with age in the same way as the quest for novelty and new experiences through leisure drops, which is

[ 116 ] - María Jesús Monteagudo y Manuel Cuenca

SIPS - PEDAGOGíA SOCIAL. REVISTA INTERUNIVERSITARIA [1139-1723 (2012) 20, 103-135] • TERCERA ÉPOCA 
estudio, defienden la continuidad de los intereses de ocio a lo largo de la vida y constatan, de acuerdo a la Teoría del Desarrollo de Ocio de Iso-Ahola, que dicha tendencia se reafirma con la edad en la misma medida en que desciende la búsqueda de novedad y nuevas experiencias a través del ocio, especialmente notoria desde las primeras fases hasta la edad adulta temprana (24-43 años).

El influjo de este modelo teórico, que subraya el peso de la preferencia por la familiaridad y el mantenimiento de patrones de ocio ya conocidos, se hace notorio en estudios que emplean el conocimiento de los patrones de ocio desarrollados durante la infancia, para predecir los futuros estilos de ocio de esas personas durante la etapa adulta. Son numerosos los estudios que sugieren que la mitad de las actividades de ocio de una persona adulta, tiene su equivalente en los patrones de ocio durante la infancia (Yoesting y Christensen, 1978; McGuire, Dottavio y O'Leary, 1987; IsoAhola, Jackson y Dunn, 1994). Si realmente un porcentaje importante de las actividades que conforman los patrones de ocio de una persona adulta tienen su origen en actividades, cuyas preferencias se desarrollaron durante la infancia, nos hallamos ante un dato con amplias repercusiones desde el punto de vista de las políticas, la gestión y la intervención educativa en materia de ocio. Si el objetivo es potenciar el valor del ocio como factor de desarrollo personal a lo largo de la vida, no es posible obviar la importancia de exponer a las personas, durante su infancia y juventud, a un amplio abanico de actividades de ocio que les permitan vivir experiencias de diversa índole, sentando las bases actitudinales y motivacionales para incrementar o retomar su participación de ocio en etapas posteriores.

No hay que obviar, sin embargo, que los mismos estudios que afirman lo antes señalado, recomiendan ser cautos con estas afirmaciones sobre la evolución general de los itinerarios de ocio. Algunos resultados obtenidos en las mismas investigaciones y en otras especially noticeable at an early stage until early adulthood (24-43 years).

The influence of this theoretical model, which emphasises the power of the preference for familiarity and the maintenance of leisure patterns already known, is evident in studies that use the knowledge of leisure patterns developed during childhood to predict the future leisure lifestyles of those people for adulthood. Numerous studies suggest that half of the leisure activities of an adult have their equivalent in leisure patterns during childhood (IsoAhola, Jackson \& Dunn, 1994; McGuire, Dottavio \& O'Leary, 1987; Yoesting \& Christensen, 1978). If indeed a significant percentage of the activities that make up the leisure patterns of an adult stem from activities whose preferences were developed during childhood, we are faced with a fact that has broad implications in terms of policy, management and educational intervention in leisure. If the goal is to enhance the value of leisure as a factor of personal development throughout life, it is not possible to ignore the importance of exposing people during their childhood and youth, to a wide range of leisure activities that allow them to have life experiences of various kinds, thus establishing the attitudinal and motivational bases to increase or resume their participation in leisure activities in later stages.

However, we should not ignore the fact that the same studies that state the above recommend caution with these statements about the general development of leisure itineraries. Some results obtained in the same research and more recent ones support the idea promoted by theories above mentioned that the level of involvement in leisure diminishes over time (Agahi, Ahacic \& Parker, 2006; Gordon et al., 1976). Similarly, the desire of novelty associated with late adolescence and early adulthood does not seem to be exclusively limited to these 
más recientes, apoyan la idea promovida por teorías antes mencionadas de que el nivel de implicación en ocio, se ve mermado con el paso del tiempo (Gordon et al., 1976; Agahi, Ahacic y Parker, 2006). Del mismo modo, el deseo de novedad asociado al final de la adolescencia y a edad adulta temprana, no parece limitarse únicamente a estos periodos (Nimrod y Kleiber, 2007). La persistencia de la búsqueda de novedad en etapas tardías de la vida, explica la incorporación de nuevas actividades de ocio en este periodo. Si bien la tendencia generalizada parece apuntar el descenso de la incorporación de actividades al repertorio de ocio, se producen algunas excepciones en las que el tipo de actividad resulta determinante (Iso-Ahola, Jackson y Dunn, 1994). El comienzo de actividades relacionadas con el desarrollo de hobbies y prácticas de ocio domésticas, tiene lugar preferentemente en etapas tardías de la vida. La relevancia de estas actividades aumenta de forma notoria con la edad, mientras que lo contrario ocurre con prácticas que exigen un esfuerzo físico importante, las relacionadas con deportes de equipo y las propias de la recreación al aire libre.

Como apuntábamos, algo similar sucede con los reemplazos de una actividad por otra. Dichas sustituciones son cada vez menos frecuentes a medida que avanza el desarrollo, en todos los tipos de actividad, excepto en hobbies y actividades de ocio "casero". Desde posiciones teóricas (Iso-Ahola, Jackson y Dunn, 1994), estos ejercicios de reemplazo son importantes porque permiten entender la tendencia hacia la novedad a través del ocio. Su existencia revela, según algunos autores, un deseo de enriquecimiento del repertorio de ocio. A nuestro parecer, tales sustituciones de una práctica por otra pueden interpretarse como estrategias de adaptación en etapas avanzadas de la vida o incluso en circunstancias vitales que requieran conductas adaptativas. Sin embargo, la incorporación de reemplazos como un rasgo persistente en el periods (Nimrod \& Kleiber, 2007). The persistence of novelty seeking in later stages of life, explains the incorporation of new leisure activities in this period. While the general trend seems to point to a decrease in the incorporation of new activities to the variety of leisure activities, there are some exceptions in which the type of activity is decisive (Iso-Ahola, Jackson \& Dunn, 1994). The beginning of activities related to the development of hobbies and domestic leisure practices, preferably takes place in later stages of life. The relevance of these activities increases markedly with age, whereas the opposite occurs with practices that require physical effort, those related to team sports and outdoor recreation.

As we mentioned, something similar happens with the replacement of one activity by another. Such substitutions are becoming less frequent as development takes place in all types of activities, except in hobbies and "at home" leisure activities. From theoretical positions (Iso-Ahola, Jackson \& Dunn, 1994), these replacement exercises are important because they allow us to understand the trend towards novelty through leisure. Its existence reveals, according to some authors, a desire to enrich the range of leisure activities. In our view, these replacements of one practice by another can be interpreted as adaptation strategies in advanced stages of life, or even in life circumstances requiring adaptive behaviours. However, the incorporation of replacements as a persistent feature on a person's leisure itinerary can be counterproductive from the point of view of the experiential process of leisure, and lead to a kind of dilettantism that hinders the proper progression of skills required for the performance of leisure and its enjoyment. It may also adversely affect the profits that are not immediate. In short, if replacement behaviours become a constant feature in a leisure itinerary, the 

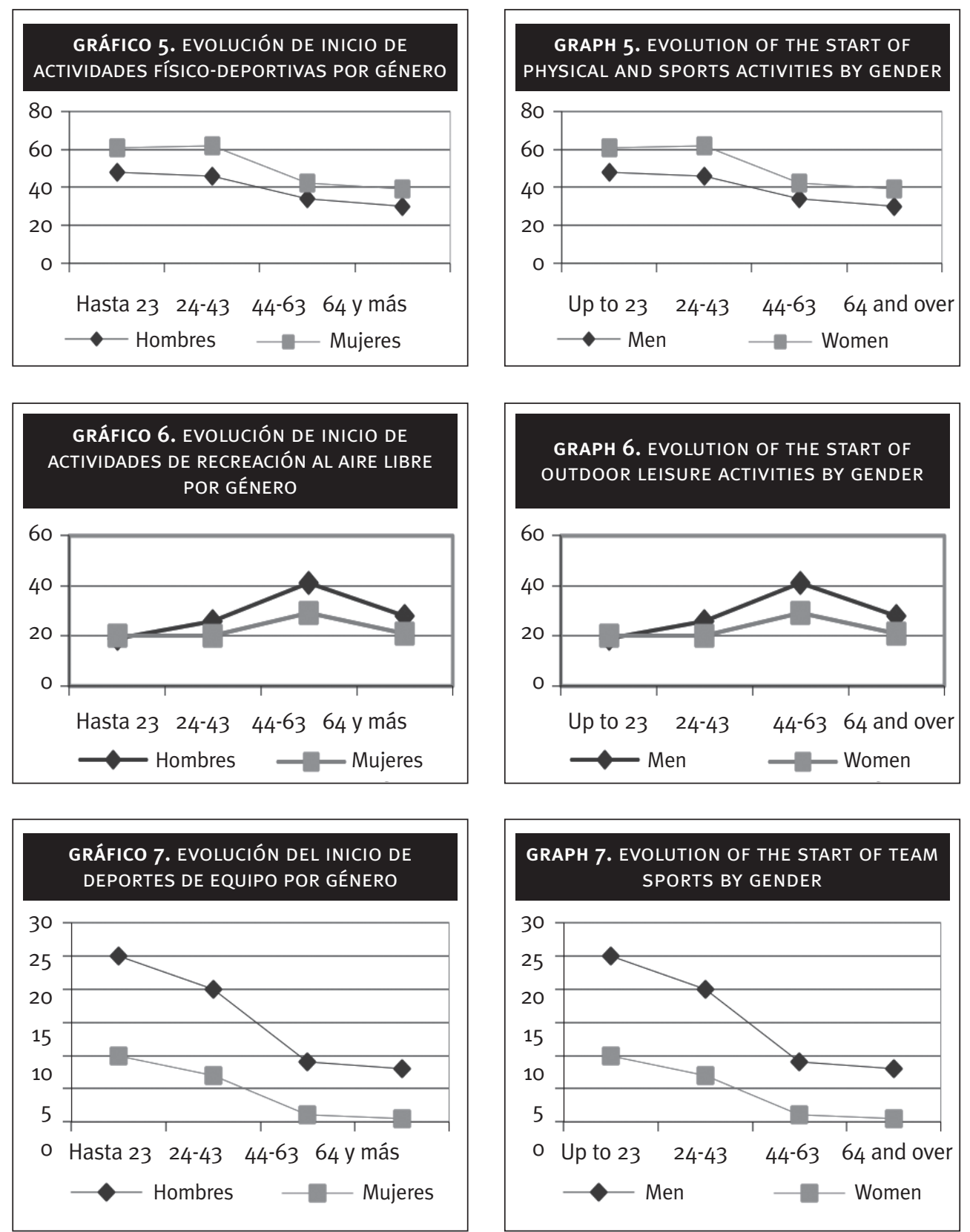

Fuente: Iso-Ahola, Jackson y Dunn, 1994

Source : Iso-Ahola, Jackson y Dunn, 1994.

itinerario de ocio de una persona puede tener efectos contraproducentes desde el punto de vista del proceso experiencial que es el ocio y desembocar en una suerte de diletantismo

chances that the stakeholders involved will transform their experience into a true leisure experience can become increasingly complex.

LOS ITINERARIOS DE OCIO DESDE LA INVESTIGACIÓN: TENDENCIAS, RETOS Y APORTACIONES [ 119 ] SIPS - PEDAGOGÍA SOCIAL. REVISTA INTERUNIVERSITARIA [1139-1723 (2012) 20, 103-135] • TERCERA ÉPOCA 


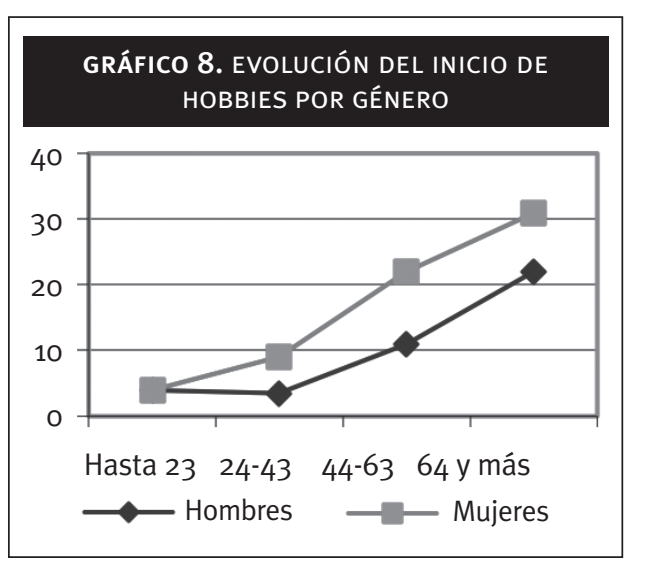

GRÁFICO 9. EVOLUCIÓN DEL INICIO DE

ACTIVIDADES DE OCIO DOMÉSTICO POR GÉNERO

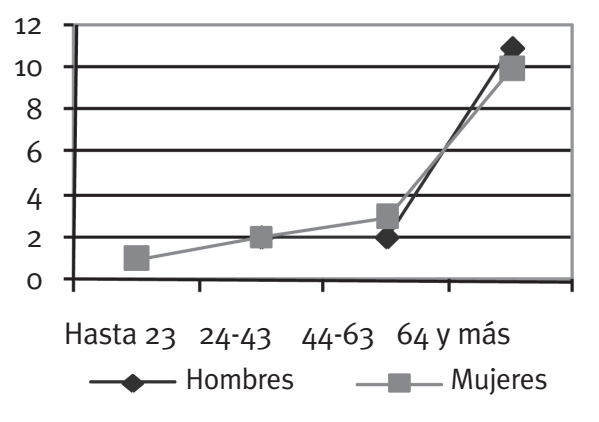

Fuente: Iso-Ahola, Jackson y Dunn, 1994.

que dificulte la adecuada progresión de las habilidades necesarias para el ejercicio del ocio y el disfrute que de éste se deriva. Igualmente, puede afectar negativamente a la obtención de beneficios que no sean de carácter inmediato. En definitiva, si las conductas de reemplazo se convierten en una constante en una trayectoria de ocio, las posibilidades de que su protagonista transforme su vivencia en una auténtica experiencia de ocio pueden tornarse cada vez más complejas.

Por el contrario, la continuidad que parece presidir la evolución de los itinerarios de ocio a lo largo de la vida no ha de entenderse como imposibilidad de cambio, sino más bien como la orientación que prevalece en las personas hacia lo familiar, siempre y cuando, la acción conocida haya resultado positiva. La dialéctica

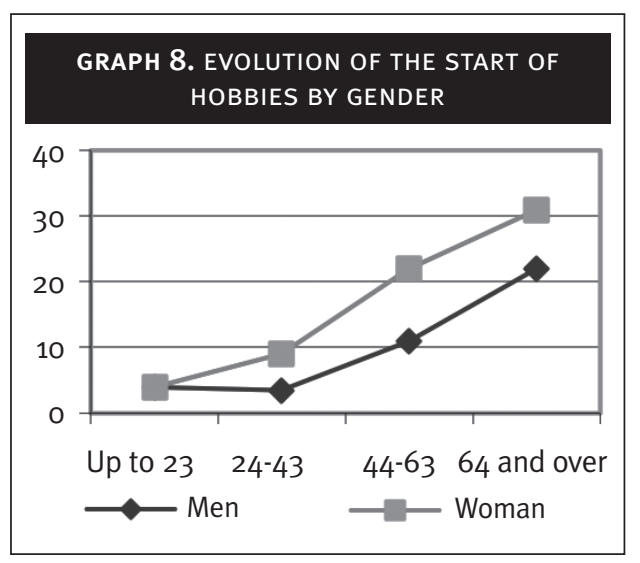

GRAPH 9. EVOLUTION OF THE START OF HOME LEISURE ACTIVITIES BY GENDER

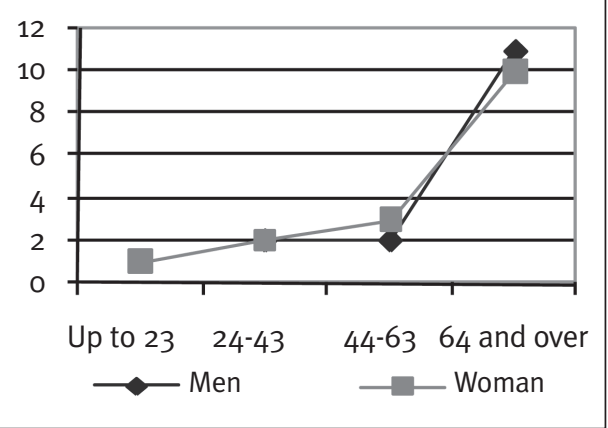

Source: Iso-Ahola, Jackson y Dunn, 1994.

On the contrary, the continuity that seems to preside over the evolution of leisure itineraries throughout life should not be understood as the impossibility of change but rather as the prevailing trend of individuals towards what is familiar to them, provided that the known action has been positive. The dialectic between continuity and change seems to be part of the mechanisms that explain the dynamic evolution of leisure, as the desire for novelty in the different stages of life persists. The main difference is the way it responds to this desire for change. From the point of view of a particular leisure practice, continuity may be a feature of a person's participation in that practice. This does not mean, however, that the development of

\section{[ 120 ] María Jesús Monteagudo y Manuel Cuenca}

SIPS - PEDAGOGÍA SOCIAL. REVISTA INTERUNIVERSITARIA [1139-1723 (2012) 20, 103-135] • TERCERA ÉPOCA 
entre continuidad y cambio parece formar parte de los mecanismos que explican el devenir dinámico del ocio, al persistir el deseo de novedad en las diferentes etapas de la vida. La principal diferencia reside en la forma en que se da respuesta a este deseo de cambio. Desde el punto de vista de una práctica de ocio concreta, la continuidad puede ser una característica de la participación de una persona en dicha práctica. Esto no significa, sin embargo, que el desarrollo de la acción no evolucione en el tiempo. Muy por el contrario, la novedad, bajo la forma de nuevos retos y convenientemente regulada por la persona, es uno de los atributos más atractivos y también, más efectivos del ocio para el mantenimiento del atractivo y el compromiso con la acción. Recordemos que la vivencia continuada de una práctica de ocio transcurre por diferentes fases, expresiones, objetivos, motivos, niveles de implicación e intensidad (Kelly y Godbey, 1992; Godbey, 1999).

Las Teorías del Desarrollo y en especial, la elaborada por Iso-Ahola (1980.b), ha contribuido a esclarecer los factores que intervienen en la evolución general de los itinerarios de ocio a lo largo de la vida. Esta aproximación, realizada desde un nivel macro (Iso-Ahola, Jackson y Dunn, 1994), ha revelado que el devenir dinámico del ocio se halla condicionado por la orientación dual de las personas hacia la estabilidad y el cambio. Las decisiones de ocio que tomamos para iniciar, continuar, sustituir o abandonar una práctica responden a la constante búsqueda de equilibrio entre estas dos tendencias que conviven en el ser humano.

Los cuatro criterios de interacción, a saber, la existencia de comienzos de actividades, reemplazos, continuidad o abandono, utilizados para desvelar la evolución general de los itinerarios de ocio, orientan también un análisis micro que repara en los ritmos intrapersonales del ocio, con el fin de categorizar a las personas según las decisiones que marcan la evolución de sus itinerarios. the action does not evolve over time. Quite the contrary, the novelty in the form of new challenges and adequately controlled by the person, is one of the most attractive and also most effective attributes of leisure to maintain the attraction and commitment to the action. We should remember that the continuous experience of a leisure practice passes through different stages, expressions, objectives, reasons, levels of involvement and intensity (Godbey, 1999; Kelly \& Godbey, 1992).

Developmental Theories and, in particular, that produced by Iso-Ahola (1980b) has helped to clarify the factors involved in the general development of the leisure itineraries throughout life. This approach, made from a macro level (Iso-Ahola, Jackson \& Dunn, 1994), has revealed that the dynamic evolution of leisure is conditioned by the dual orientation of people towards stability and change. The leisure decisions we take to start, continue, replace or abandon a practice are a response to the constant search for balance between these two tendencies that coexist in human beings.

The four interaction criteria, namely, the existence of early activities, replacements, continuity or abandonment used to reveal the general development of leisure itineraries, also lead to a microanalysis that focuses on the intrapersonal rhythms of leisure, in order to categorise people according to the decisions that mark the evolution of their itineraries. 


\subsection{Las diferencias intrapersonales}

La aproximación, desde un nivel micro permite un acercamiento particular al Estilo de Vida de Ocio (EVO) de cada individuo. Por ello, la información obtenida constituye la materia prima necesaria para intervenir desde ámbitos como la educación, counseling del ocio, ocio preventivo o terapéutico. Uno de los aspectos en los que más útil se ha revelado el estudio de los itinerarios de ocio desde este enfoque ha sido la identificación de estilos de ocio pasivos frente a los activos (Lazcano, Madariaga y Doistua, 2010). Conocidos los beneficios de mantenerse activo a diferentes niveles (físico, intelectual y social), la detección de estilos de ocio pasivo en el itinerario de ocio de un individuo o colectivo permite idear estrategias de intervención que reorienten la participación en ocio de esas personas o incorporen nuevas alternativas a sus estilos de ocio.

El Modelo de Toma de Decisiones de Ocio (Jackson y Dunn, 1988), se utiliza desde este enfoque con el propósito de identificar qué variables resultan significativas a la hora de explicar por qué las personas deciden abandonar, añadir nuevas actividades, continuar o sustituir una práctica por otra. La clasificación de las personas según estas decisiones, da lugar a cuatro categorías corroboradas en diferentes investigaciones (Jackson y Dunn, 1988; Searle, Mactavish y Brayley, 1993; Iso-Ahola, Jackson y Dunn, 1994, Monteagudo, 2011).

- Polifacéticos, Agregadores o Heterogéneos: Este grupo está conformado por aquellas personas que llevando a cabo ya una práctica de ocio, incorporan otra nueva sin abandonar la anterior.

- Reemplazadores: Esta categoría aúna a los individuos que deciden interrumpir la práctica de ocio que desarrollan para sustituirla por otra.

- Constantes, perseverantes o continuistas: Se trata de aquellas personas que de-

\subsection{Intrapersonal differences}

The approach, from a micro level, allows a particular approach to the leisure lifestyle of each individual. Therefore, the information obtained is the raw material needed to intervene from areas such as education, leisure counselling, preventive or therapeutic leisure. One of the aspects that has proved most useful to the study of leisure itineraries from this approach has been the identification of passive forms of leisure as opposed to active ones (Lazcano, Madariaga \& Doistua, 2010). Knowing the benefits of being active at different levels (psychical, intellectual and social), the identification of passive forms of leisure in the leisure itinerary of an individual or group allows us to devise intervention strategies that redirect leisure participation of those people, or incorporate new alternatives to their forms of leisure.

The Model of Leisure Decision-Making (Jackson \& Dunn, 1988) is based on this approach in order to identify which variables are significant in explaining why people decide to leave, add new activities, maintain or replace one practice by another. The classification of people according to these decisions results in four categories corroborated by several studies (Iso-Ahola, Jackson \& Dunn, 1994; Jackson \& Dunn, 1988; Searle, Mactavish \& Brayley, 1993; Monteagudo, 2011).

- Multifaceted people, Adders or Heterogeneous people: This group is comprised of those people who, although they are already carrying out a leisure practice, incorporate a new one without leaving the previous one.

- Replacers: This category comprises individuals who decide to discontinue the leisure practice they develop to replace it with another one.

- Constant, persistent or continuers: Those individuals who decide to con-

[ 122 ] - María Jesús Monteagudo y Manuel Cuenca

SIPS - PEDAGOGÍA SOCIAL. REVISTA INTERUNIVERSITARIA [1139-1723 (2012) 20,103-135] • TERCERA ÉPOCA 
ciden dar continuidad a su práctica, evitando cesar la misma, sustituirla o incorporar una nueva actividad

- Rupturistas o supresores: Integran esta categoría las personas que deciden abandonar una práctica que realizaban sin iniciar ninguna otra.

Las investigaciones sugieren la importancia de algunas variables capaces de discriminar entre personas pertenecientes a cada categoría: la edad, años de educación formal, actitud hacia el ocio, satisfacción con el ocio y nivel de participación en ocio. Atendiendo a la capacidad predictiva de estas variables, se observaron similitudes entre individuos pertenecientes a las categorías: polífacéticos y reemplazadores, y entre continuadores y rupturistas. Las personas de las dos primeras categorías, resultaron ser más jóvenes, con mejor actitud hacia el ocio, más satisfechos con este ámbito y con mayores niveles de participación. Los reemplazadores resultaron ser quienes poseían un mayor nivel

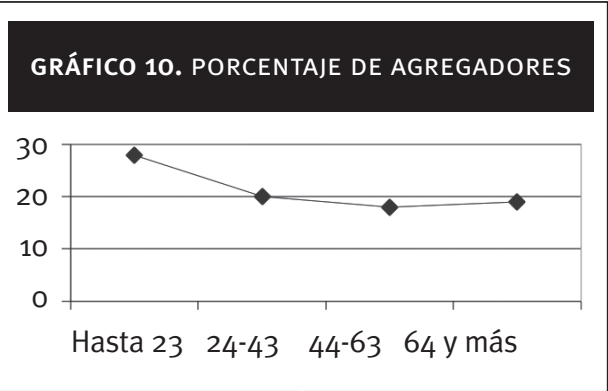

Fuente: Iso-Ahola, Jackson y Dunn, 1994
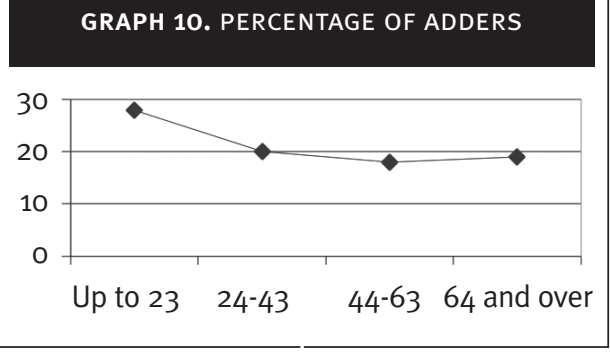

Source: Iso-Ahola, Jackson \& Dunn, 1994. tinue with their practice, avoiding to cease it, replace it, or add a new activity.

- Ground-breaking people or quitters: This category comprises individuals who decide to abandon a practice they carried out without starting another one.

Research suggests the importance of some variables able to discriminate between people belonging to each category: Age, years of formal education, leisure at titude, leisure satisfaction and level of leisure participation. Based on the predictive power of these variables, there were similarities between individuals belonging to these categories: multifaceted and replacers, and between continuers and ground-breaking people. People in the first two categories were found to be younger, with better attitude toward leisure, more satisfied with this area, and with higher lev-
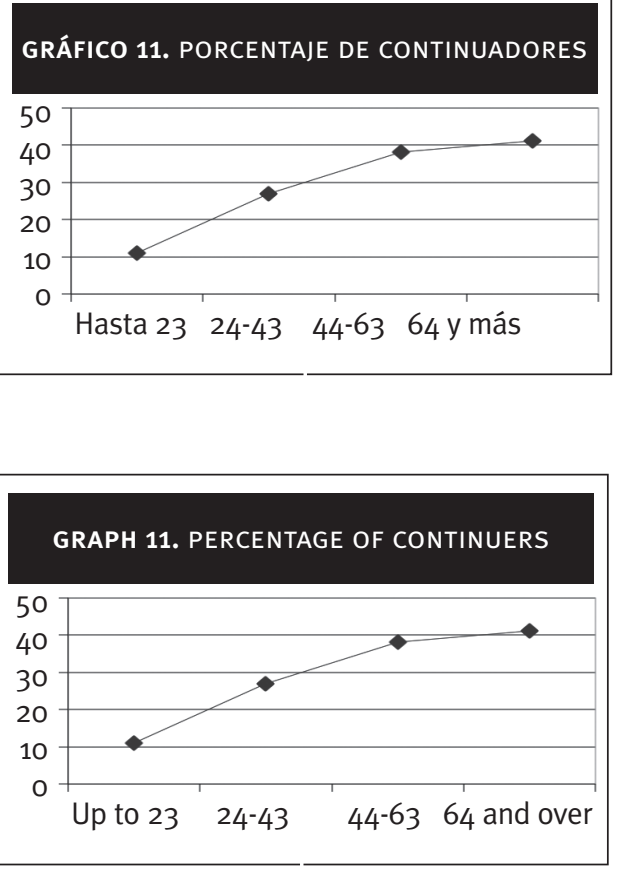

LOS ITINERARIOS DE OCIO DESDE LA INVESTIGACIÓN: TENDENCIAS, RETOS Y APORTACIONES [ 123 ] SIPS - PEDAGOGÍA SOCIAL. REVISTA INTERUNIVERSITARIA [1139-1723 (2012) 20, 103-135] • TERCERA ÉPOCA 


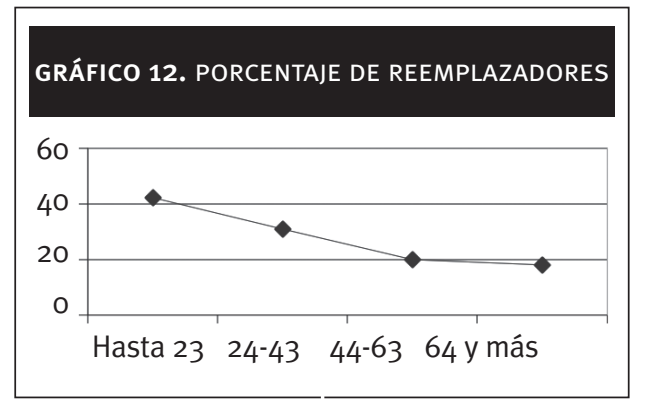

Fuente: Iso-Ahola, Jackson y Dunn, 1994.

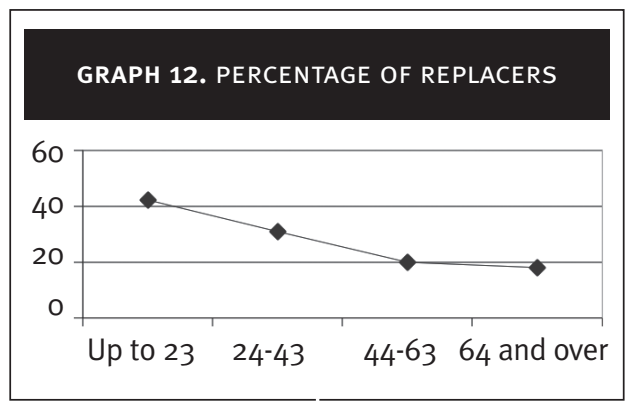

Source: Iso-Ahola, Jackson y Dunn, 1994.

formativo. Por el contrario, los continuadores eran los menos formados (Searle, Mactavish y Brayley, 1993). El género y el tipo de actividad también se muestran como variables relevantes (Iso-Ahola, Jackson y Dunn, 1994; Kleiber, Walker y Mannell, 2011).

Considerando el protagonismo de cada grupo en las distintas etapas del ciclo vital, los perseverantes o continuistas conforman el grupo más importante y aumenta en cada fase; por el contrario, los polifacéticos representan un porcentaje cada vez menor a medida que se avanza en edad, con la única excepción del último periodo de la vida en el que aumenta ligeramente el porcentaje de personas que inicia nuevas prácticas. Una tendencia que se hace más marcada entre los hombres (Iso-Ahola, Jackson y Dunn, 1994). Entendemos que el fenómeno del reemplazo se concentra en las primeras etapas de la vida y adquiere menos relevancia desde la edad adulta temprana (24-43). A partir de ese momento, este grupo se hace progresivamente menor a medida que aumenta la edad, aun-
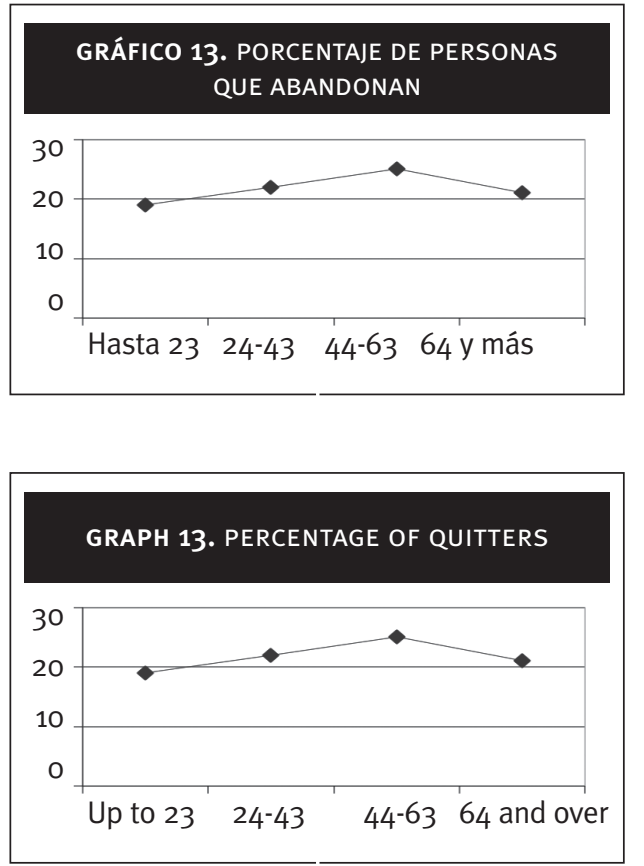

els of involvement. Replacers had a higher level of training. By contrast, continuers were the least trained (Searle, Mactavish \& Brayley, 1993). Gender and the type of activity also appeared as relevant variables (Iso-Ahola, Jackson \& Dunn, 1994; Kleiber, Walker \& Mannell, 2011).

Considering the role of each group at the different stages of the life-cycle, persistent people or continuers make up the largest group and increases in each stage; on the contrary, multifaceted people represent a percentage that decreases with age, with the only exception of the last period of life in which the percentage of people starting new practices slightly increases. This trend is more pronounced among men (Iso-Ahola, Jackson \& Dunn, 1994). We understand that the replacement phenomenon is concentrated in the early stages of life and becomes less significant from early adulthood (24-43). From that moment, this group becomes progressively smaller with increasing age, although in the last stage,

[ 124 ] • María Jesús Monteagudo y Manuel Cuenca

SIPS - PEDAGOGÍA SOCIAL. REVISTA INTERUNIVERSITARIA [1139-1723 (2012) 20, 103-135] • TERCERA ÉPOCA 
que en la última fase, se detecta una ralentización del descenso. Finalmente, el grupo de los rupturistas, es decir, de quienes abandonan, aumenta progresivamente hasta la edad adulta media (44-63 años), para después descender levemente durante la última etapa. Según esto, a medida que aumenta la edad, las personas practican un número menor de actividades de ocio; sin embargo, sumando a este descenso del abandono en las últimas fases, el incremento de quienes continúan, es lícito pensar que las actividades que se desarrollan en estos años son, también, más estables.

La incidencia del abandono y su evolución en el ciclo vital ha resultado ser uno de los temas que más interés ha recabado, por su conexión con el fenómeno de las barreras que afectan a la participación y al disfrute del ocio, pero también se ha revelado como uno de los aspectos más complejos (Jackson, 2005; Hutchinson y Kleiber, 2005). La réplica de los estudios más representativos (Searle, Mactavish y Brayley, 1993; Iso-Ahola, Jackson y Dunn, 1994) muestra una falta de consenso importante. Algunos resultados sugieren que el porcentaje de abandonos desciende con la edad (Jackson y Dunn, 1988), mientras que otros revelan una tendencia al aumento, aunque matizado con cierto descenso entre la edad adulta media y tardía (Searle y Jackson, 1985; Searle, Mactavish y Brayley, 1993). En esta misma línea, estudios más recientes afirman que, aunque las barreras tienen lugar en las distintas etapas de la vida, su impacto sobre las decisiones y conductas de ocio varía en cada momento, debido al mayor o menor manejo de estrategias de afrontamiento o capacidad de negociación de la que se disponible (Hubbard. y Mannell, 2001; Son, Mowen y Kerstetter, 2008).

La reflexión en relación al abandono nos remite al ámbito deportivo, en el cual este fenómeno se ha convertido en una prioridad, entre otras razones, por las implicaciones que el receso de práctica deportiva puede tener en a slowing of the decline is detected. Finally, the ground-breaking group, that is, those who decide to abandon, increases progressively until middle age (44-63 years), and then drops slightly during the last stage. Accordingly, as age increases, people engage in fewer leisure activities; however, if we add the decline of abandonment in the later stages and the increase of those who continue, it is legitimate to conclude that the activities carried out in these years are also more stable.

The effect of abandonment and its evolution in the life cycle has emerged as one of the issues that has aroused most interest due to its connection with the phenomenon of the barriers that affect leisure participation and enjoyment, but has also emerged as one of the most complex aspects (Hutchinson \& Kleiber, 2005; Jackson, 2005). The results of the most representative studies (Iso-Ahola, Jackson \& Dunn, 1994; Searle, Mactavish \& Brayley, 1993) show a significant lack of consensus. Some results suggest that the percentage of abandonment decreases with age (Jackson \& Dunn, 1988), whereas others have indicated an increasing trend, although with some decrease between middle and late adulthood (Searle \& Jackson, 1985; Searle, Mactavish \& Brayley, 1993). Along this same line, more recent studies claim that although barriers occur at different stages of life, their impact on leisure decisions and behaviours vary each time due to the different management of copying strategies or negotiation capacity available (Hubbard \& Mannell, 2001; Son, Mowen \& Kerstetter, 2008).

The reflection in relation to abandonment refers us to the sports field, where this phenomenon has become a priority, among other reasons, for the implications that the decrease in sports practice can have on health and quality of life. The research is mainly focused on the stage of adolescence 
el ámbito de la salud y la calidad de vida. La investigación se orienta preferentemente a la etapa de la adolescencia y juventud, etapas en las que el abandono se revela más alarmante. Estudios comparativos a nivel europeo (Pieron, 2001; Telama, Naul, Nupponen, Rychtecky y Voulle, 2002; European Commission. Directorate General Education and Culture y TNS Opinion y Social, 2010), corroboran que el abandono crece exponencialmente entre los 12 y 16 años y su alcance supera ya, en Europa, el 30\%. Los últimos informes sobre hábitos de la población española (García Ferrando, 2006; 2011), afirman que el abandono deportivo constituye un rasgo consolidado en la estructura de la práctica deportiva en España y que, aunque posee un carácter generalizado, afecta a diferentes colectivos de manera desigual. Jóvenes y adolescentes se ven especialmente afectados por el abandono; un fenómeno que se hace más evidente, si cabe, entre las chicas, tal y como lo demuestran numerosos estudios (Sanz, 2005; Cecchini et al., 2005; Molinero et al., 2005; Fernández, 2007; Martínez de Quel Pérez, Fernández y Camacho, 2010).

\section{Retos y aportaciones del concepto Itinerario a los Estudios de Ocio}

La incorporación del concepto de itinerarios a los Estudios de Ocio resulta ser algo nuevo en la trayectoria de esta disciplina. No se ha localizado en la literatura revisada ninguna investigación que, de manera explícita, aborde este concepto; sin embargo, son numerosas las investigaciones que, desde la Psicología del Ocio y apoyándose en las Teorías del Ciclo Vital, pretenden clarificar los procesos de evolución que los estilos de ocio experimentan a lo largo de la vida. A pesar del protagonismo concedido al proceso evolutivo como variable configuradora de los patrones de cambio en las trayectorias personales de ocio, estas teorías no renuncian al influjo de variables pertenecientes a la dimensión social del ser humano. and youth, when the abandonment is more alarming. Comparative studies at European level (European Commission. Directorate General Education and Culture \& TNS Opinion \& Social, 2010; Pieron, 2001; Telama, Naul, Nupponen, Rychtecky \& Voulle, 2002) have confirmed that abandonment grows exponentially between 12 and 16 years of age, which in Europe is already over 30\%. Recent reports on the habits of Spanish people (Garcia Ferrando, 2006; 2011) argue that the abandonment of sporting activities is a consolidated feature of sports practice in Spain, and that, although it has a general character, it affects different groups unevenly. Youth and adolescents are particularly affected by abandonment, a phenomenon that becomes even more evident among girls, as evidenced by numerous studies (Cecchini et al., 2005; Fernandez, 2007; Martinez de Quel Perez, Fernandez \& Camacho, 2010; Molinero et al., 2005; Sanz, 2005).

3. Challenges and contributions of the Itinerary concept to Leisure Studies

The incorporation of the concept of itineraries to Leisure Studies is new in the history of this discipline. In the reviewed literature, we have not found any studies explicitly addressing this concept; however, numerous research studies from the Psychology of Leisure, based on the Life Cycle Theories, seek to clarify the evolution processes that leisure styles experience throughout life. Despite the prominence given to the evolutionary process as a variable that makes up the change patterns in personal leisure patterns, these theories do not give up the influence of variables belonging to the social dimension of human beings. 
Como objeto de estudio, la aplicación del concepto de itinerario al fenómeno del ocio, abre nuevos frentes de investigación, al tiempo que han de reconocerse las contribuciones realizadas desde los Estudios de Ocio para comprender el comportamiento humano.

\subsection{Algunos retos en el estudio de los Itinera- rios de Ocio}

El conocimiento de los itinerarios de ocio es aún muy precario. Son todavía muy escasas las investigaciones que profundizan en este fenómeno desde el enfoque del ciclo vital y desde un abordaje integral del ocio que contemple sus diferentes expresiones a lo largo de la vida. A pesar de las dificultades metodológicas que conllevan, los estudios longitudinales resultan esenciales para delimitar los patrones de cambio que experimenta el ocio en la vida de una persona o de los miembros de una misma generación a lo largo del tiempo, disipando así las dudas generadas en estudios trasversales, -centrados en el análisis sincrónico del ocio en diferentes grupos de edad-, sobre el impacto de las divergencias generacionales en el itinerario de ocio. A esto ha de añadirse la urgencia de superar algunas de las limitaciones encontradas en las investigaciones revisadas sobre el ocio a lo largo de la vida. En ellas se repara, preferentemente, en parámetros asociados a la coordenada objetiva de las experiencias de ocio tales como actividad, tiempo y espacio. Su análisis no abunda, sin embargo, en aspectos subjetivos de la experiencia de ocio (San Salvador del Valle, 2008) tan relevantes como el impacto de la experiencia de ocio satisfactoria en la adherencia al ocio, la incidencia del ocio serio en la consolidación del compromiso con la práctica realizada o la contribución de la percepción de experiencias de ocio valioso en los sentimientos de bienestar en las diferentes etapas de la vida.

A la luz de lo planteado en estos párrafos, se hace necesario revisar y ampliar los
As an object of study, the application of the concept of itinerary to the leisure phenomenon opens up new lines of research, while at the same time recognising the contributions made by Leisure Studies to understand human behaviour.

3.1. Some challenges in the study of Leisure Itineraries

The knowledge of leisure itineraries is still very precarious. There are still very few research studies that explore this phenomenon from the life-cycle approach and from a comprehensive approach to leisure that includes its different manifestation throughout life. In spite of the methodological difficulties involved in longitudinal studies, they are essential to define the patterns of change within the leisure life of a person or members of the same generation over time, thus dispelling the doubts generated by cross-sectional studies, -focused on the synchronic analysis of leisure in different age groups-, on the impact of generational differences in the leisure itinerary. To this must be added the urgency of overcoming some of the limitations found in the reviewed research on leisure throughout life. They are mainly taken into consideration with regard to parameters associated to the objective of leisure experiences such as activity, time and space. However, their analysis does not focus on subjective aspects of the leisure experience (San Salvador del Valle, 2008) as relevant as the impact of the satisfactory leisure experience for the adherence to leisure, the incidence of serious leisure in the consolidation of the commitment to practice, or the contribution of the perception of valuable leisure experiences to the feelings of well-being at different stages of life.

In the light of the points made in the above paragraphs, it is necessary to revise and expand the criteria that have been tra- 
criterios que, tradicionalmente, han sido empleados como baremos para la identificación y el análisis de los cambios que el ocio experimenta a lo largo de la vida. Quizá los criterios de corte cuantitativo tales como la participación, medida en número de actividades y frecuencia de las mismas, no sean suficientes para abordar la cuestión del cambio en las historias de ocio desde un enfoque actual. La tendencia a la continuidad que parece prevalecer en nuestras conductas de ocio no debe refutarse o corroborarse atendiendo únicamente los niveles de participación habidos en etapas anteriores o al mantenimiento de los intereses de ocio alimentados en fases previas. Quizá, una de las claves para entender el fenómeno de la continuidad reside en el deseo de mantener y consolidar aquellas prácticas vividas como experiencias de ocio satisfactorias. Sin obviar el influjo de otras variables de naturaleza psicosocial, nos atrevemos a subrayar, el protagonismo de la satisfacción como uno de los grandes motores que dirige las conductas de ocio y explica su persistencia. Mantenemos o retornamos a aquellas experiencias que nos resultan satisfactorias; esto es, aquellas cuyo balance entre beneficios y costes (inversión de tiempo, esfuerzo, dinero...) se resuelve a favor de los primeros. En la medida que conductas de ocio previas no hayan sido percibidas como fuentes de satisfacción, las personas recurren al cambio en sus patrones de ocio. Cambios que, como se ha visto, forman parte de la esencia del ocio y de su evolución a lo largo de la vida. Su presencia puede adquirir un valor adaptativo en ocasiones en las que el cambio supone una mejora en el itinerario de ocio o, un carácter rupturista cuando impide avanzar en el proceso de desarrollo personal que conlleva toda práctica de ocio satisfactoria. La caracterización psicosocial de la experiencia de ocio y su impacto, parece, en este sentido, un criterio más adecuado para la evaluación de las tendencias del ocio ditionally used as for the identification and analysis of the changes that leisure experiences throughout life. Quantitative criteria such as participation, measured in number of activities and their frequency, may not be sufficient to address the issue of change in leisure histories from a current approach. The trend to continuity that seems to prevail in our leisure behaviour should not be refuted or corroborated based only on participation levels in earlier stages, or on the maintenance of leisure interests in previous stages. One of the keys to understanding the phenomenon of continuity may lie in the desire to maintain and strengthen those practices experienced as satisfactory leisure experiences. Without ignoring the influence of other psychological variables, we dare to emphasise the key role of satisfaction as one of the driving forces that directs leisure behaviour patterns and explains their persistence. We maintain or return to those experiences that we find satisfactory; that is, those whose balance between benefits and costs (investment of time, effort, money...) is decided on the former. Insofar as previous leisure patterns have not been perceived as sources of satisfaction, people turn to a change in their leisure patterns. These are changes that, as we have seen, are part of the essence of leisure and its evolution throughout life. Their presence can sometimes acquire an adaptive value when change is an improvement on the leisure itinerary, o a ground-breaking nature when it does not allow individuals to make progress in the process of personal development involved in every successful leisure practice. The psychosocial description of the leisure experience and its impact seems, in this sense, a more appropriate criterion for the assessment of leisure trends throughout the life cycle. This is a rather more qualitative criterion that, without doubt, is more in line with 
durante el ciclo vital. Un criterio, de naturaleza más cualitativa que, sin duda, se muestra más acorde con el nuevo paradigma de ocio centrado en la experiencia (Monteagudo, 2008; Cuenca, 2011).

El reto que plantea el estudio del ocio desde el enfoque del ciclo vital, atendiendo a estos parámetros, nos induce a analizar, explicar y predecir los cambios que afectan al ocio a lo largo de la vida, desde baremos, tales como la intensidad de las experiencias de ocio, los beneficios percibidos y la contribución de su ocio a su satisfacción vital en cada etapa. Junto a ellos, interesa conocer el significado y valor atribuido al ocio en cada periodo o la percepción de libertad que tienen las personas en distintos momentos, reparando en la vivencia de barreras y estrategias de afrontamiento disponibles en cada fase como respuesta a esas dificultades. En definitiva, este nuevo abordaje del ocio en cuanto historia de vida gira su atención hacia aquellas variables que son claves en la definición de ocio entendido como experiencia humana.

\subsection{Principales aportaciones}

Desde un enfoque estrictamente académico, una de las principales aportaciones de la aplicación del concepto itinerarios al estudio del ocio reside en la consolidación del tratamiento del ocio como proceso; con este tratamiento, se refuerza la relevancia del ocio como factor de desarrollo humano a lo largo de la vida y se legitima su impulso a través de políticas específicas, modelos de gestión y medidas concretas de intervención.

El interés práctico que ha despertado el estudio de los itinerarios de ocio radica especialmente en su valor predictivo. Disponer de información relevante acerca de la evolución general de los patrones de ocio en los distintos momentos de la vida hace posible prever la vivencia de momentos críticos, etapas de máxima potencialidad desde el punto de the new leisure paradigm focused on experience (Cuenca, 2011; Monteagudo, 2008).

The challenge posed by the study of leisure from the life-cycle approach, taking into account these parameters, leads us to analyse, explain and predict the changes that affect leisure throughout life, based on criteria such as the intensity of the leisure experiences, the perceived benefits, and the contribution of their leisure to life satisfaction at every stage. In addition, it would be interesting to know the meaning and value attached to leisure in each period, or the perception of freedom that people have at different times, with special focus on the experience of barriers and coping strategies available at each stage in response to these difficulties. In short, this new approach to leisure in life history focuses on those variables that are key to understanding the definition of leisure as a human experience.

\subsection{Main contributions}

From a strictly academic approach, one of the main contributions of the application of the concept of itineraries to leisure studies lies in strengthening the treatment of leisure as a process; this treatment reinforces the importance of leisure as a factor of human development throughout life, and is promoted through specific policies, management models and specific measures of intervention.

The practical interest that has sparked the study of leisure itineraries mainly lies in its predictive value. Having relevant information about the general development of leisure patterns at different times of life makes it possible to predict the experience of critical moments, stages of maximum potential from the point of view of personal 
vista del desarrollo personal y social o periodos en los que el ocio, requiere la puesta en marcha de medidas de intervención concretas, ya sean éstas educativas, psicológicas y comunitarias.

Más concretamente, el estudio de los itinerarios de ocio puede tener una incidencia considerable en la:

- Orientación de la oferta educativa, mediante la consideración de aspectos tales como el predominio del deseo de novedad o continuidad en cada etapa; la promoción de estilos de ocio adecuados en la edad adulta, mediante la exposición durante la infancia y juventud, a repertorios de ocio suficientemente amplios y variados; la creciente relevancia de la preferencia por los hobbies y la cierta persistencia del deseo de innovación durante la edad adulta tardía; la aparición e incidencia de barreras, generando estrategias adecuadas de afrontamiento y/o negociación, que eviten o mitiguen su impacto.

- Segmentación de la acción, mediante agrupamientos o tipologías de personas, generadas a partir de la identificación de estilos o patrones de ocio, basados en el tipo de interacción que se establece con el ocio. Uno de los criterios óptimos para esta segmentación sería considerar el tipo de evolución de las experiencias de ocio de las personas, o colectivos, en el itinerario vital y generar tipologías en base a tal evolución; en vez de centrar las agrupaciones en variables sociodemográficas o en los tipos de actividades desarrolladas. - Orientación de estrategias de intervención en ocio, a partir de la detección de estilos de ocio que entrañen cierto riesgo entre distintos grupos de población, bien por la escasez o falta de ocio (ocio ausente), por su direccionalidad (negativa) o por los atributos que caracterizan las experiencias de ocio (por ejemplo, excesivamente sedentarios, pasivos, con claros desajustes and social development or periods in which leisure requires the implementation of specific intervention measures, whether educational, psychological or community.

More specifically, the study of leisure itineraries can have a significant impact on the:

- Approach to the educational offer, by considering aspects such as the prevalence of the desire for novelty or continuity at each stage; the promotion of appropriate leisure styles in adulthood by exposure during childhood and youth, to a wide range of leisure activities; the growing importance of the preference for hobbies, and a persistent desire for innovation during late adulthood, the occurrence and incidence of barriers, generating appropriate strategies for coping and/or negotiation, to avoid or mitigate its impact.

- Action segmentation by groups or types of people, generated from the identification of leisure styles or patterns, based on the type of interaction established with leisure. One of the optimum criteria for this segmentation is to consider the type of evolution of the leisure experiences of individuals or groups in the life course, and generate typologies according to this development instead of focus groups based on socio-demographic variables or the types of activities carried out.

- Approach to leisure intervention strategies, based on the identification of leisure styles that involve some risk between different population groups, due to a shortage or lack of leisure (leisure lack), for their (negative) directionality or for the attributes that characterise leisure experiences (for example, excessively sedentary, passive, with clear imbalances in the development of the leisure dimensions). The early identi-

[ 130 ] • María Jesús Monteagudo y Manuel Cuenca

SIPS - PEDAGOGÍA SOCIAL. REVISTA INTERUNIVERSITARIA [1139-1723 (2012) 20, 103-135] • TERCERA ÉPOCA 
en el desarrollo de las dimensiones del ocio). La identificación precoz o, al menos, a tiempo de estas circunstancias, puede inspirar las políticas de ocio y los modelos educativos. Este tipo de información constituye, además, la materia prima necesaria para la intervención educativa, el counseling o la educación del ocio.

- Promoción de Estilos de Ocio óptimo y duraderos a través de la Adherencia al ocio. La garantía de la satisfacción como pieza principal para promover la continuidad, junto con la direccionalidad positiva del ocio desarrollado, son algunos de los ingredientes necesarios para conseguir que el ocio se experimente como un factor de desarrollo personal. Sin el libre deseo de continuidad, que explica la adherencia al ocio, se coarta la naturaleza procesual del ocio y se limitan todas sus potencialidades a largo plazo.

Lejos de la aproximación al estudio del ocio desde el tiempo libre o la actividad, la investigación actual avanza con la sólida convicción de que el ocio es, ante todo, una experiencia personal compleja (direccional y multidimensional), centrada en actuaciones queridas (libres y satisfactorias), autotélicas (con un fin en sí mismas) y personales (con implicaciones individuales y sociales) (Cuenca, 2006:14). Sin renunciar a su carácter social, la experiencia de ocio se adentra en el terreno de lo subjetivo y adopta distintas expresiones, intensidades y significados que enriquecen su esencia pero que, sin duda, plantean un complejo reto en su estudio.

La consideración del ocio como experiencia a lo largo de la vida ha puesto de relieve su legitimidad como proceso que se materializa en un itinerario de ocio. El concepto de itinerario aplicado al fenómeno del ocio se ajusta perfectamente a su carácter procesual y a la necesidad de incorporar, a su estudio, un enfoque holístico que permita entender el ocio en el marco de la unidad dinámica y psi- fication, or at least, before these circumstances occur, can inspire leisure policies and educational models. This information is also the raw material necessary for educational intervention, counselling or leisure education.

- Promotion of optimal and lasting Leisure Styles through adherence to leisure. The guarantee of satisfaction as the cornerstone to promote continuity, along with the positive leisure directionality developed, are some of the ingredients needed for leisure to be experienced as a factor of personal development. Without the free pursuit of continuity, which explains adherence to leisure, the procedural nature of leisure is inhibited and all its long-term potentialities are limited.

Far from the approach to the study of leisure focused on free time or leisure activity, current research is undertaken with the strong belief that leisure is, above all, a complex, personal experience (directional and multidimensional), focused on desired (free and satisfactory), autotelic (being an end in themselves) and personal (with individual and social implications) actions (Cuenca, 2006:14). Without losing its social character, the leisure experience goes into the realm of the subjective, and takes different expressions, intensities and meanings that enrich its essence, but certainly pose a complex challenge in its study.

The consideration of leisure as a lifelong experience has highlighted its legitimacy as a process that is embodied in a leisure itinerary. The concept of itinerary applied to the leisure phenomenon fits perfectly with its procedural nature and the need to incorporate, in its study, a holistic approach to understanding leisure as part of the dynamic and psychosocial unit embodied in a person's life history. 
cosocial que es la historia de ocio de una persona.

El concepto de itinerario de ocio se revela, a la luz de la investigación, como una herramienta válida para el estudio del ocio a lo largo de la vida. Por un lado, por su ajuste a los presupuestos teóricos en los que descansa la investigación actual sobre el ocio: su valor experiencial y su carácter procesual. Pero también por su capacidad para analizar, explicar y predecir los cambios que afectan al ocio en las diferentes etapas de la vida, sentando así las bases de potenciales intervenciones que contribuyan a consolidar el papel del ocio como factor de desarrollo personal.

\section{Referencias bibliográficas / References}

Agahi, N.; Ahacic, K \& Parker, M. (2006). Continuity of participation from middle age to old age. Journal of Gerontology, 61, 340-346.

Armstrong, G. K. \& Morgan, K. (1998). Stability and change in levels of habitual physical activity in later life. Age and Ageing, 27, 17-23.

Atchley, R. C. (1989). A continuity theory of normal aging. The Gerontologist, 29, 183-190.

Bellver, M C. (2005): La Educación para la Salud en la familia como prevención de conductas antisociales. Pedagogía Social. Revista Interuniversitaria, 12-13, pp. 43-57.

Bigné, E.; Font, X. y Andreu, L. (2000). Marketing de destinos turísticos. Análisis y estrategias de desarrollo. Madrid: Esic.

Cecchini, J.A., Méndez, A. y Contreras, O.R. (2005). Motivos de abandono de la práctica del deporte juvenil. Cuenca: Universidad de Castilla-La Mancha.

Cuenca, M., (2000). Ocio humanista. Dimensiones y manifestaciones actuales del ocio. Documentos de Estudios de Ocio, 16. Bilbao: Universidad de Deusto.

Cuenca, M., (coord.) (2006). Aproximación multidisciplinar a los Estudios de Ocio. Documentos de Estudios de Ocio, 31. Bilbao: Universidad de Deusto.
The concept of leisure itinerary appears, in the light of research evidence, as a successful tool for the study of lifelong leisure. On the one hand, it fits with the theoretical assumptions on which the current research on leisure rests: its experiential value and procedural nature. On the other hand, it enhances the ability to analyse, explain and predict the changes that affect leisure at different stages of life, thus laying the foundations for potential interventions that will help to strengthen the role of leisure as a factor of personal development.

Cuenca, M., Aguilar, E. y Ortega, C., (2010). Ocio para innovar. Documentos de Estudios de Ocio, 42. Bilbao: Universidad de Deusto.

Cuenca, J. (2011). El valor de la experiencia de ocio en la Modernidad Tardía. Bilbao: Universidad de Deusto. Tesis Doctoral.

Cumming, E. \& Henry, W., (1961). Growing old. Nueva York: Basic Books.

Erikson, E. H. (1985). El ciclo vital completado. Buenos Aires. Paidós.

European Commission. Directorate General Education and Culture y TNS Opinion y Social (2010). Sport and physical activity. Eurobarometer 72.3. Brussels: European Union. Recuperado de: http://ec.europa.eu/publicopinion/index_en.htm

Fernández, E. (2007). Barreras para la práctica deportiva de las mujeres españolas durante la infancia y la juventud. ADOZ. Revista de Estudios de Ocio, 31, 49-57.

García Ferrando, M. (2006). Postmoderrnidad y deporte: entre la individualización y la masificación: encuesta sobre hábitos de los españoles 2005, Madrid: Ministerio de Educación, Cultura y Deporte. Consejo Superior de Deportes.

García Ferrando, M. y Llopis, R. (2011). Ideal democrático y bienestar personal. Encuesta sobre los hábitos deportivos en España 2010. Madrid: Consejo Superior de Deportes y Centro de Investigaciones sociológicas. 
Godbey, G. (1999). Leisure in your life. An exploration. 5th edition. State Collage: Venture Publishing.

Gordon; C.; Gaitz, C.M. \& Scott, J. (1976). Leisure and lives. Personal expressivity across life span. In R.H. Binstock y E. Shanas (eds.). Handbook of aging and the social sciences (pp. 310-341). Nueva York. Van Nostrand Reinhold.

Havighurst, R. J. (1973). Developmental tasks and education. Nueva York: David Mcakay. Recuperado de: http://feadef.iespana.es/santander/conf/co/ o.pieron.pdf.

Hubbard, J. \& Mannell, R. (2001). Testing competing models of the leisure constraint and negotiation process in a corporate employee recreation setting. Leisure Sciences, 23, 145-163.

Hutchinson, S. L. \& Kleiber, D. A. (2005). Leisure, constraints, and negative life events: Paradox and possibilities. En Jackson E. L. (ed.), Constraints to leisure (pp. 137-150). State College, PA: Venture.

Iso-Ahola, S. (1980a). The social psychology of leisure. Dubuque: William Brown.

Iso-Ahola, S. (1980b) Toward a dialectical social psychology of leisure and recreation. En Iso-Ahola S. (ed.). Social psychology perspectives on leisure and recreation (pp. 19-37), Springfield, IL.: Charles Thomas.

Iso-Ahola, S.; Jackson, E. \& Dunn, E. (1994). Starting, ceasing and replacing leisure activities over the lifespan. Journal of Leisure Research, 26, 227249.

Iwasaki,Y. y Smale, B. J. A. (1998). Longitudinal analyses of the relationships among life transitions, chronic health problems, leisure, and psychological well-being. Leisure Sciences, 20, 25-52. Jackson, E.L. \& Dunn, E. (1988). Integrating ceasing participation with other aspects of leisure behavior. Journal of Leisure Research, 20, 31-45.

Jackson, E. L. (2005). Impacts of life transitions on leisure and constraints to leisure. En Jackson E.L. (ed.), Constraints to leisure, (pp. 115-136). State College, PA: Venture.

Jackson, E.L. (dir.) (2006). Leisure and the quality of life: impacts of social, economic and cultural development: Hangzhou Consensus. Hangzhou, China: Zhejiang University Press.

Janke, M., Davey, A. \& Kleiber, D.A. (2006). Modeling change in older adults' leisure activities. Leisure Sciences, 28, 285-303.
Kelly, J.R. \& Godbey, G. (1992). The sociology of leisure. State College: Venture Publishing.

Kleiber, D. A. (1999). Leisure experience and human development. A dialectical interpretation. Nueva York: Basic Books.

Kleiber, D.A.; Walker, G.J. \& Mannell, R.C. (2011). A social psychology of leisure ( $2^{\underline{\underline{a}}}$ ed.). State College: Venture Publishing.

Lazcano, I.; Madariaga, A. y Doistua, J. (2010). El envejecimiento activo y su incidencia en la experiencia de ocio. ADOZ. Revista de Estudios de Ocio, 33, 117-147.

Lee, R. E. \& King, A. C. (2003). Discretionary time among older adults: How do physical activity promotion interventions affect sedentary and active behaviors? Annual in Behavioral Medicine, 25, 112-119.

Levinson, D. J. (1978). The season of a man's life. New York: Alfred A. Knopf.

Martínez de Quel Pérez, O.; Fernández, E. y Camacho, M.J. (2010). Percepción de dificultades para la práctica de actividad física en chicas adolescentes y su evolución con la edad. Apunts, 99, 1ํㅡㄴ mestre, 92-99.

Masnou, M. y Puig, N. (1995). El acceso al deporte: los itinerarios deportivos. En Blázquez D. (ed.) La iniciación deportiva y el deporte escolar (pp. 371394). Barcelona: Inde Publicaciones

McClelland, K.A. (1982). Self conception and life satisfaction: integrating age subculture and Activity theory. Journal of Gerontology, 37 (6), 723-732.

Molinero, O.; Salguero, A.; Tabernero, B.; Tuero, C. y Márquez, S. (2005). El abandono deportivo: propuesta para la intervención práctica en edades tempranas. Lecturas: Educación Física y Deportes (Revista digital), 10, 90.

Monteagudo, M.J. (2008). Reconstruyendo la experiencia de ocio: características, condiciones de posibilidad y amenazas en la sociedad de consumo. En Monteagudo M.J. (ed.) La experiencia de ocio: una mirada científica desde los Estudios de Ocio (pp. 81-110). Documentos de Estudios de Ocio, 35. Bilbao: Universidad de Deusto.

Monteagudo, M.J. (2011). Los itinerarios de ocio deportivo. Estudio de los jóvenes de Bizkaia (19952005). Bilbao: Universidad de Deusto. Tesis Doctoral.

Neugarten, B.; Havighurst, R. \& Tobin, S. (1961). The measurement of life satisfaction. Journal of Gerontology, 16, 134-143. 
Nimrod, G \& Kleiber, D.A. (2007). Reconsidering change and continuity in later life: toward an innovation theory of successful aging. International Journal of Aging and Human Development, 65, 122.

Pieron, M. (2001). Participación de jóvenes europeos en actividades físicas y deportivas, actitudes hacia la escuela y la Educación Física. Consecuencias pedagógicas (112-132). En Mazón V. et al. (eds.) Reflexiones y perspectivas de enseñanza de la Educación Física y el Deporte escolar en el nuevo milenio. Santander: A.D.E.F. Cantabria.

Puig, N. y Masnou, M. (1988). Los itinerarios deportivos de la población juvenil. Revista de Estudios de Juventud, 32, 45-56.

Reitzes, D.C.; Mutran, E.J. \& Verrill, L.A. (1995). Activities and self-esteem. Research on Aging, 17, 260277.

San Salvador del Valle, R. (2008). O fenómeno do Ócio nas Cidades do século XXI. En Cuenca M. y J. Clerton (orgs.) Ócio para viver no Século XXI (pp.107-124). Fortaleza. As Musas.

Sanz, E. (2005). La práctica físico-deportiva en el tiempo libre en universitarios. Análisis y propuestas de mejora. Logroño: Universidad de La Rioja.

Sagy, S.; Antonovsky, I. \& Adler, I. (1990). Explaning life satisfaction in later life: The sense of coherente model and activity theory. Behavior, Health and Aging, 1 (1), 11-25.

\section{Notas}

${ }^{1}$ Definición adaptada del concepto de itinerario deportivo de Puig y Masnou (1995:371).

${ }^{2}$ Los movimientos conocidos como Slow, aplicados al ámbito de la Gastronomía, Educación, vida urbana, u otros movimientos tales como el Downshifting, caracterizados por el ensalzamiento de valores cercanos al ocio por su contribución a la calidad de vida, son buen ejemplo del influjo del ocio y de sus presupuestos en otras esferas de la vida.
Searle, M.A.; Mactavish, J.B. \& Brayley, R.E. (1993). Integrating ceasing participation with other aspects of leisure behavior. Journal of Leisure Research, 25 (4), 389-404.

Son, J.S.; Mowen, A. J. \& Kerstetter, D.L. (2008). Testing alternative Leisure Constraint Negotiation Models: an extension of Hubbard and Mannell's Study. Leisure Sciences, 30, 198-216.

Stebbins, R. A. (2000). Un estilo de vida óptimo de ocio: combinar ocio serio y casual en la búsqueda del bienestar personal. En Cuenca M. (ed.) Ocio humano y desarrollo. Propuestas para el $6^{0}$ congreso Mundial de Ocio (pp. 109-116). Bilbao: Universidad de Deusto.

Telama, R.; Naul, R.; Nupponen, H.; Rychtecky, A. \& Voulle, P. (2002). Physical fitness, sporting lifestyles and olympics ideals: cross-cultural studies on youth sport in Europe. International Council of Sport Science and Physical Education. Schorndorf: Verlag Karl Hofman.

Trilla, J. (1984). La educación no formal. Barcelona: Barcanoa.

Uth, T.C. (1996). Definitions of life style and its applications to travel behavior. Recuperado de: www.i4.auc.dk/ trg/td/papers/papers96/tr_og_ad/ uth/uth.pdf

Yoesting, D.R. \& Christensen, J.E. (1978). Reexamining the significance of childhood recreation patterns on adult leisure behavior. Leisure Sciences, 1, 27-38.

\section{Notes}

\footnotetext{
${ }^{1}$ Definition adapted from the concept of sports itinerary by Puig \& Masnou (1995:371).

2 The movements known as Slow, applied to the field of gastronomy, education, urban life, or other movements such as Downshifting, characterized by the exaltation of values close to leisure for their contribution to the quality of life are good example of the influence of leisure and its assumptions in other areas of life.
} 
DIRECCIÓN DE LOS AUTORES /

AUTHORS' ADDRESSES: Universidad de Deusto.

Instituto de Estudios de Ocio.

Avda. Universidades, 24. 48007 - Bilbao, Spain.

Correos electrónicos / e-mail:

mjmonte@deusto.es,mcuenca@deusto.es

Fecha de recepción del artículo /

received date: 16.II.2012

Fecha de revisión del artículo/

reviewed date: 10.V.2012

Fecha de aceptación final/

accepted date: 12.V.2012

\section{COMO CITAR ESTE ARTÍCULO /} HOW TO CITE THE ARTICLE:

Monteagudo, M. J. y Cuenca, M. (2012). Los itinerarios de ocio desde la investigacion: Tendencias, retos y aportaciones. Pedagogia Social. Revista Interuniversitaria, 19, pp. 103-135.

Monteagudo, M. J. \& Cuenca, M. (2012). Leisure Itineraries from a Research Perspective: Trends, Challenges and Contributions. Pedagogia Social. Revista Interuniversitaria, 20, pp. 103-135. 